\title{
Corporate entrepreneurship: a systematic literature review and future research agenda
}

\author{
David Urbano $\mathbb{D} \cdot$ Andreu Turro $\cdot$ Mike Wright $•$ \\ Shaker Zahra
}

Accepted: 28 November 2021 / Published online: 5 January 2022

(C) The Author(s) 2022

\begin{abstract}
This article analyzes the state of the art of the research on corporate entrepreneurship, develops a conceptual framework that connects its antecedents and consequences, and offers an agenda for future research. We review 310 papers published in entrepreneurship and management journals, providing an assessment of the current state of research and, subsequently, we suggest research avenues in three different areas: corporate entrepreneurship antecedents, dimensions and consequences. Even though a significant part of the overall corporate entrepreneurship literature has appeared in the last decade, most literature reviews were published earlier. These reviews typically cover a single dimension of the corporate entrepreneurship phenomenon and, therefore, do not provide a global perspective on the existing literature. In addition, corporate entrepreneurship has been studied from different fields and there are different approaches and definitions
\end{abstract}

D. Urbano $(\bowtie) \cdot$ A. Turro

Department of Business, Universitat Autònoma de

Barcelona, Building B, Campus UAB, 08913 - Cerdanyola

del Vallès, Barcelona, Spain

e-mail: david.urbano@uab.cat

A. Turro

e-mail: andreu.turro@uab.cat

D. Urbano $\cdot$ A. Turro

Centre for Entrepreneurship and Social Innovation

Research (CREIS), Universitat Autònoma Barcelona,

Building S, Campus Sabadell UAB, C/ Emprius 2, 08202 -

Sabadell, Barcelona, Spain to it. This limits our understanding of accumulated knowledge in this area and hampers the development of further research. Our review addresses these shortcomings, providing a roadmap for future research.

Plain English Summary This review analyzes the articles published in the corporate entrepreneurship field and presents the future research agenda. Research agrees that corporate entrepreneurship has a positive impact on firms' profits and growth. This has generated an increase in the number of research articles published in this area. However, previous literature has some limitations and areas that should be further explored. First, there are many different definitions and terms to refer to corporate entrepreneurship activities. This makes it difficult to understand the current state of corporate entrepreneurship research. Second, we lack up to date comprehensive literature reviews summarizing the

\footnotetext{
M. Wright

Centre for Management Buy-Out Research, Imperial

College Business School University of Ghent, Exhibition

Road, London SW7 2AZ, UK

e-mail: mike.wright@imperial.ac.uk

S. Zahra

Strategic Management \& Entrepreneurship Department, Carlson School of Management, Gary S. Holmes Center for Entrepreneurship, 3-430 Carlson School, Minneapolis, MN, USA

e-mail: zahra004@umn.edu
} 
knowledge and advances generated in the field in the last years. Overall, the objective of this research is to explore the content and evolution of corporate entrepreneurship research. This research contributes by summarizing and synthesizing the main findings in previous literature. It also contributes by identifying relevant inconsistencies and ambiguities in previous literature that have prevented the development of certain areas within the corporate entrepreneurship field.

Keywords Corporate entrepreneurship . Intrapreneurship - Corporate venturing - Strategic renewal $\cdot$ Systematic literature review $\cdot$ Bibliometrics

\section{JEL Classification $\quad$ L25 $\cdot$ L26}

\section{Introduction}

Corporate entrepreneurship (CE) has generated considerable research attention because of its importance to corporate vitality and economic wealth generation (Dess et al., 2003). Past studies from several complementary fields, such as strategy, finance, entrepreneurship or marketing, have contributed to a better understanding of complex and dynamic entrepreneurship within established organizations (Hornsby, et al., 2013). CE is widely considered important for facilitating a firm's efforts to exploit its current competitive advantages and explore new opportunities and the competencies required to pursue them successfully. Hence, it is widely viewed as contributing to the evolution of a firm's corporate strategy (Ireland et al., 2003) by building new capabilities and businesses that enable renewal, foster strategic change and enhance a company's profits and growth (Narayanan et al., 2009; Zahra \& Hayton, 2008; Zahra, 1996a).

However, despite the growing research in the last few years, there are aspects where we still lack understanding (Hornsby et al., 2009; Phan et al., 2009) as "the theoretical and empirical knowledge about the domain of $\mathrm{CE}$ and the entrepreneurial behavior on which it is based are still key issues that warrant a deeper understanding" (Kuratko et al., 2015, p.247). Since it has been studied from different fields, different definitions and approaches to the CE phenomenon have appeared (Simba \& Thai, 2019). This fragmentation makes it more difficult to understand the current state of CE research. In this regard, some previous research has used interchangeably different terms, such as, intrapreneurship (Pinchot, 1985), corporate venturing (McMillan, 1986) or corporate internal entrepreneurship (Schollhammer, 1982) as synonyms of CE (Antoncic \& Hisrich, 2001; Parker, 2011). These differences in terminology and the fact that some studies do not build on each other make it difficult to evaluate and compare results across studies (Narayanan et al., 2009). Overall, this limits our understanding of the CE phenomenon, hamper the development of further knowledge in this area, and make it more difficult to establish relations and boundaries with other relevant constructs (Shepherd et al., 2015).

In addition, there are few literature reviews focusing specifically on the CE phenomenon (Dess et al., 2003; Narayanan et al., 2009; Phan et al., 2009). Moreover, most of these articles focus only on specific dimensions of the CE phenomenon, and thus do not provide an overall perspective on the literature in this field. This limits the capacity of these studies to provide an integrative framework that summarizes and captures the state-of-the-art literature in the $\mathrm{CE}$ field. Narayanan et al. (2009), for example, examine corporate venturing and propose an organizing and integrative framework to guide future research. Similarly, Minola et al. (2016) focus on corporate venturing in family businesses. In the case of Dess et al. (2003), the authors attempt to identify emerging issues in CE by focusing specifically on its role in inducing and cultivating organizational learning. Therefore, while informative, these analyses are limited since other CE fundamental activities (such as innovation or strategic renewal) are not part of their remit. Thus, we are missing an up to date comprehensive review that covers the knowledge and advances generated in the field. In this regard, systematic literature reviews are particularly appropriate approaches to highlight the key contents from the literature in a structured way. Focusing on aspects such as the most prestigious journals, the most relevant authors in the field or analyzing the specific contents studied, can contribute to provide an enhanced understanding about the trend a research field is taking (Mourao \& Martinho, 2020). It is important to address this gap to provide a meaningful assessment of how the CE literature has continued to evolve beyond earlier reviews and to set out new directions for research in this area. Hence, this article addresses the question: How 
has the field of corporate entrepreneurship research evolved, as reflected in articles published in top management and entrepreneurship journals? Based on this, we develop a systematic literature review and provide a conceptual framework and agenda for future research.

This article makes several contributions to literature. First, we develop a systematic literature review of 310 papers published in the top journals of the management and entrepreneurship fields and we analyze and discuss key aspects in the CE literature (such as, the most cited articles, authors and topics of analysis). In addition, through a citation and co-citation analysis, we provide a map that explains the intellectual structure of the CE phenomenon (Ramos-Rodriguez \& Ruiz-Navarro, 2004). Hence, we contribute by summarizing and synthesizing the main findings in previous literature. In doing so, we develop a conceptual framework in which we outline and assess the main antecedents, dimensions and consequences of CE activity (Kolev et al., 2019). In this regard, although a very significant part $(54 \%)^{1}$ of the overall $\mathrm{CE}$ research has been published in the last decade, most literature reviews were published earlier. A few introductions to special issues have been published in the last years (Corbett et al., 2013; Kuratko et al., 2015; Minola et al., 2021; Phan et al., 2009). These articles typically explain the relevance of the CE phenomenon, summarize the evolution of the CE field and suggest future research. However, these papers do not develop an in-depth literature review analysis as they focus mostly on highlighting the key findings of the papers that are part of the special issue. Thus, although relevant, their contributions are incomplete as they do not provide a comprehensive overview and analysis of the research in this area. Second, we also contribute by identifying relevant inconsistencies, ambiguities and gaps in previous literature that have prevented a more detailed understanding of certain areas within the CE field. Based on this, we provide a research agenda for the future.

The remainder of the paper is structured as follows. In the next section we provide a summary of the main definitions on CE. Next, we explain the methodology of the study (our journal selection and systematic literature review). We then describe the study's main findings.

\footnotetext{
$\overline{1}$ See Table 1 for more information.
}

Finally, we position our findings in relation to existing literature and suggest future research directions.

\section{Definitions and scope}

CE research focuses on ways in which companies create new businesses that generate new revenue streams and value for shareholders (Narayanan et al., 2009). In this regard, the concept of $\mathrm{CE}$ has evolved over time and several definitions have appeared. Guth and Ginsberg (1990) explained that CE embodies two different phenomena: new venture creation within existing organizations and the transformation of ongoing organizations through strategic renewal. One of the most extensively used definitions is that by Sharma and Chrisman (1999, p. 18). They define it as "the process whereby an individual or a group of individuals, in association with an existing organization, create a new organization or instigate renewal or innovation within that organization." Other previous research use the terms CE and intrapreneurship indistinctively (Hornsby et al., 2002). From this perspective, Antoncic and Hisrich (2001, p. 498) use an even broader definition of intrapreneurship, to denote "entrepreneurship within an existing organization." Later, some studies explicitly differentiated between CE and intrapreneurship (Stam, 2013). Following Pinchot (1985), Stam refers to intrapreneurship or entrepreneurial employee activity as the development of new business activities by an employee; hence, it follows a bottom-up approach. In contrast, $\mathrm{CE}$ is considered a decision initiated by the top management team and subsequently implemented to the lower hierarchical levels of the organization.

Overall, there are different types of CE (i.e., sustained regeneration, organizational rejuvenation, strategic renewal or domain redefinition) and organizations that exhibit $\mathrm{CE}$ are viewed as dynamic, flexible entities able to take advantage of new opportunities when they arise (Dess et al., 2003). Among such organizations, there is an acceptance of risk and an understanding that the outcomes of innovation are uncertain (Bloodgood et al., 2015). CE is concerned with various forms of newness (e.g., organizational renewal, innovation, and establishing new ventures) and affects organizational survival, growth and performance (Zahra, 1991, 1996a). Following Sharma and Chrisman (1999) we adopt a broad perspective 


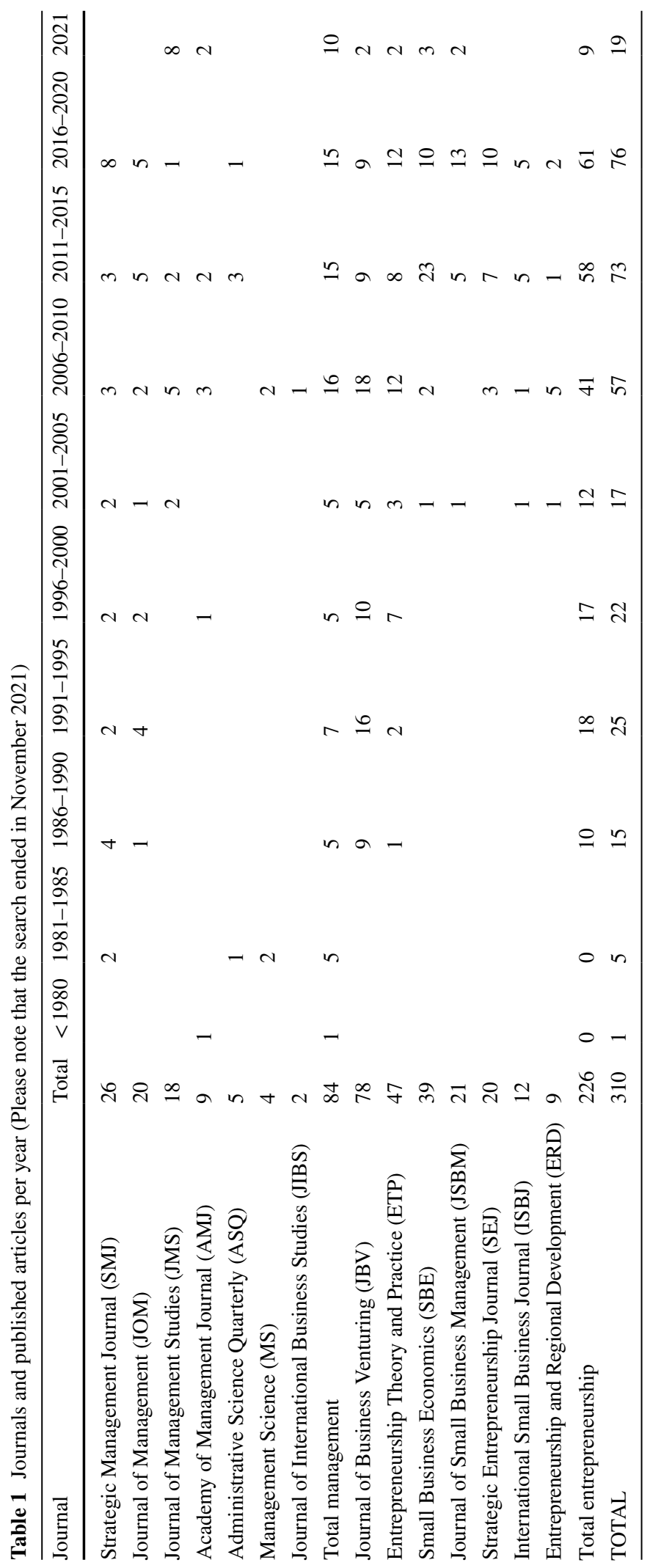


of CE. Specifically, we consider CE as those initiatives that take place within companies and that aim at creating and adding new business, or at fostering innovation, change and renewal. In the next section, we present the methodology employed to review the literature using this broad approach.

\section{Methodology}

We conducted a systematic literature review and used a bibliometric approach to analyze and describe the findings. Analyzing the bibliometric structure of a specific body of literature allows for increased objectivity (compared with other forms of literature review) and enables the researcher to sift through large amounts of data (Wallin, 2012). Bibliometrics (combined with author citation analysis techniques) have found advocates in the fields of entrepreneurship and innovation (Schildt et al., 2006). To our knowledge, this approach has not yet been undertaken in the specific CE literature.

Our research was carried out in several steps. First, as other authors in the management and entrepreneurship fields (e.g., Schildt et al., 2006), we used the Social Sciences Citation Index (SSCI) from the Web of Science to search for conceptual and empirical articles. We analyzed exclusively full-length articles as they are considered to be validated knowledge (López-Duarte et al., 2016; Phan et al., 2009; Urbano et al., 2019). Doctoral theses, books or conference proceedings were not considered in this review. The search was conducted following the most commonly used terms in the literature to describe the entrepreneurial activities that occur within organizations: "corporate entrepreneurship," "intrapreneurship," "corporate venture," "corporate venturing," "internal entrepreneurship," "strategic renewal," "entrepreneurial employee activity," "sustained regeneration," and "organizational rejuvenation." We searched for these words in the title, abstract, keywords, and text of the articles and did not limit our search to any specific period of time. Hence, the oldest paper dates back to 1969 (Westfall, 1969) and the most recent were published in 2021 (the search ended in November 2021). These terms are consistent with the definitions and forms of $\mathrm{CE}$ mentioned above. It is extremely unlikely that an article related to $\mathrm{CE}$ is published without using them. Other related terms, such as, organizational creativity, organizational ambidexterity, business model innovation or entrepreneurial orientation were excluded from our search because they are beyond the scope of our analysis.

Second, following an approach similar to Busenitz et al. (2014) and Marvel et al. (2016), our search was restricted to top or high impact journals in order to control for overall research quality. From this perspective, the first search round focused on those outlets that are widely agreed to be top journals in the management field. The journals included have the highest five-year impact factor in the 2020 Journals Citations Report (JCR). ${ }^{2}$ These are: Journal of Management (JOM, 16.662), Academy of Management Journal (AMJ, 15.873), Administrative Science Quarterly (ASQ, 14.365), Journal of International Business Studies (JIBS, 13.555), Strategic Management Journal (SMJ, 12.226), Journal of Management Studies (JMS, 10.960), and Management Science (MS, 6.619). This first search round yielded 100 articles, however, only 84 remained as 16 were discarded. The reason for this is that although they appeared in the results of the initial search, when analyzing the papers in detail, they used the above terms only in the references section (not in the title, abstract, keywords or text of the articles).

Subsequently, we searched the top entrepreneurship and small business journals with the highest five-year impact factor in the 2020 JCR. These are: Journal of Business Venturing (JBV, 15.732), Entrepreneurship Theory and Practice (ETP, 15.191), Strategic Entrepreneurship Journal (SEJ, 10.636), Small Business Economics (SBE, 8.139), International Small Business Journal (ISBJ, 7.220), Journal of Small Business Management (JSBM, 6.799), and Entrepreneurship and Regional Development (ERD, 6.142). Using the previous criteria, in this second round, out of a total of 283 articles, 226 remained. Overall, this search yielded 310 papers. The appendix of this paper provides a list of all the articles included.

Third, all papers were read, analyzed, coded, and classified by the authors. Differences in classification

\footnotetext{
$\overline{2 \text { The journals }}$ are part of the Business and Management categories. Initially, we searched in the Finance and Economics categories as well. However, no articles were found in these categories. For the same reason, the Marketing and Consumer research journals were also dismissed.
} 
were resolved by discussion between the authors. The following information was collected for each article: authors' names, number of authors per article, publication year, publication journal, theoretical perspective, research objective, type of research (theoretical or empirical), methodology and research technique applied, level of analysis, database origin (country), authors' affiliation (country), main findings, number of citations and reference list. In addition, we use a co-citation analysis which is defined as the frequency with which two documents (or two authors) are cited together (Small, 1973). This technique has been used to map the intellectual structure of various fields of research such as the diffusion of innovations (Cottrill et al., 1989), macroeconomics (McCain, 1983) or strategic management (Ramos-Rodriguez \& RuizNavarro, 2004; Shafique, 2013). This type of analysis considers that citations can be used as indicators of present and past activities of scientific work. Hence, it is based on the idea that authors cite those documents they consider to be relevant for their research (Post et al., 2020). This analysis was performed using VOSviewer (Mourao \& Martinho, 2020; van Eck \& Waltman, 2010).

\section{Findings}

The results of literature reviews are often explained by differentiating between the quantitative and qualitative aspects of the analysis (Clark et al., 2014). From a quantitative point of view, research describes, measures and counts the main results of the analysis. This may include the sources of publication, authors, articles, citations or publishing countries. Conversely, a qualitative analysis (e.g., content analysis) of the results includes the study of the main topics and trends, generally by explaining whether and how the content of the topic has evolved over time (Clark et al., 2014).

\subsection{Descriptive analysis}

Our results show that the number of articles on CE per journal and year has increased significantly (Table 1). In the period 2006-2010, 57 papers were published, more than three times the number of articles in the previous five years (17 articles in the 2001-2005 period). This trend continued in the
Table 2 Most cited articles

\begin{tabular}{ll}
\hline Article & $\begin{array}{l}\text { Total cita- } \\
\text { tions in } \\
\text { SSCI }\end{array}$ \\
\hline Miller (1983) & 2203 \\
Anderson et al. (2014) & 1136 \\
Ahuja and Morris Lampert (2001) & 1105 \\
Burgelman (1983) & 1096 \\
Zahra and Covin (1995) & 927 \\
Zahra (1991) & 645 \\
Jones et al. (2011) & 592 \\
Zahra (1996a) & 592 \\
Walter et al. (2006) & 591 \\
Birkinshaw (1997) & 552
\end{tabular}

2011-2015 period when 73 papers were published and it is confirmed in the period 2016-2020 with 76 papers published. This development in the last decade is explained by the entrepreneurship journals (rather than the management ones) and is related to the publication of several special issues (Bettinelli et al., 2017; Covin \& Lumpkin, 2011; Kuratko et al., 2015). Overall, 54\% of research in the CE field published in top and high impact journals has appeared in the last decade (168 out of the 310 papers studied came out in 2011 or later). Table 1 also shows that this trend is more evident for entrepreneurship than for management journals. In terms of specific journals, $J B V$ is the most prolific as it accounts for the vast majority of publications ( $25 \%$ of the articles; 78 out of 310 papers). To analyze the impact of the articles, we used the number of their SSCI total citations. The most cited article by far is that by Miller (1983) (2353 citations), which studies the determinants of entrepreneurship in established companies and develops a typology of three different types of firms. Table 2 presents information on the most cited articles.

Overall, the articles reviewed are written by 537 different authors and on average, each article has 2.6 authors. The most prolific in terms of publications are Covin (21 articles), Zahra (18 articles), and Kuratko (18 articles). Table 3 shows that, for instance, the 18 articles published by Zahra have produced 5787 citations in SSCI, which represents $17.1 \%$ of the total citations produced by the 310 articles studied. In addition, in $64 \%$ of the articles reviewed in Table 1 at 
Table 3 Authors sorted by number of articles

\begin{tabular}{lllll}
\hline Author & $\mathrm{N}^{\mathbf{o}}$ of citations & $\mathrm{N}^{\mathbf{o}}$ of articles & $\begin{array}{l}\text { Overall } \% \\
\text { citations }\end{array}$ & Author's affiliation \\
\hline Zahra, SA & 5787 & 18 & 17,1 & USA \\
Covin, JG & 3099 & 21 & 9,2 & USA \\
Miller, D & 2627 & 2 & 7,8 & Canada \\
Kuratko, DF & 2024 & 18 & 6,0 & USA \\
Burgelman, RA & 1631 & 2 & 4,8 & USA \\
Hornsby, JS & 1367 & 11 & 4,0 & USA \\
Anderson, N & 1136 & 1 & 3,4 & UK \\
Potocnik, K & 1136 & 1 & 3,4 & UK \\
Zhou, J & 1136 & 1 & 3,4 & USA \\
Ahuja, G & 1105 & 1 & 3,3 & USA \\
Lampert, CM & 1105 & 1 & 3,3 & USA \\
\hline
\end{tabular}

least one of the authors is from a US university (198 out of 310). This percentage is more than four times higher than the following country, the UK (14\%); 43 articles (out of 310) have at least one author from a British university. This prevalence of American (and Anglo-Saxon) based researchers is common but has begun to change in more recent years.

Most papers are empirical $(76 \%, 237$ out of 310) and quantitative (63\%, 196 articles). These articles use mostly data for one single country, as shown in Table 4, in most cases the samples used contain information only for US companies $(54.1 \%, 106$ out of 196). In addition, studies using global datasets are not very common in CE research since only $11.2 \%$ of the articles use data with information for 3 or more countries (22 out of 196). We also studied the differences in the number of citations depending on the methodology applied: qualitative researches have an average of 72 citations, whereas quantitative works have an average of 109 . These differences are statistically not significant.

Finally, following past practice in the literature (e.g., Ramos-Rodriguez \& Ruiz-Navarro, 2004; Schildt et al., 2006; Wallin, 2012), Fig. 1 shows the main intellectual structure of $\mathrm{CE}$ research (only the most co-cited researches are shown in the graph) where each circle represents an article. Specifically, the diameter of these circles (and the size of its corresponding labels) is proportional to the number of citations and articles with similar co-citation profiles tend to show up close to each other (van Eck \& Waltman, 2010). That is, "if two articles are cited in the same paper, they are considered to be closely related to each other either because they belong to the same topic area or their topic areas are closely connected" (Schildt et al., 2006, p. 400). Similarly, the lines linking different circles/articles show which articles have been cited together in the same paper (to simplify the graph, the lines appear only for those articles that have been cited together 10 times or more).

Overall, Fig. 1 shows that the papers on the lefthand side are some of the most cited articles in the CE (Miller, 1983) and entrepreneurial orientation (Lumpkin \& Dess, 1996) fields. These highlight the relationship between $\mathrm{CE}$ and strategy (Burgelman, 1983a, 1983b), the effect of CE on firm performance (Zahra, 1991, 1995) or, in some cases, they discuss

Table 4 Database country of origin

\begin{tabular}{llr}
\hline Database origin & $\mathrm{N}^{\mathbf{o}}$ of articles & $\%$ \\
\hline USA & 106 & 54,1 \\
3 or more countries & 22 & 11,2 \\
Spain & 11 & 5,6 \\
2 countries & 9 & 4,6 \\
Sweden & 8 & 4,1 \\
Italy & 7 & 3,6 \\
China & 5 & 2,6 \\
Germany & 4 & 2,0 \\
Ireland & 3 & 1,5 \\
Netherlands & 3 & 1,5 \\
UK & 3 & 1,5 \\
Others & 15 & 7,7 \\
Total & 196 & 100,0 \\
\hline
\end{tabular}




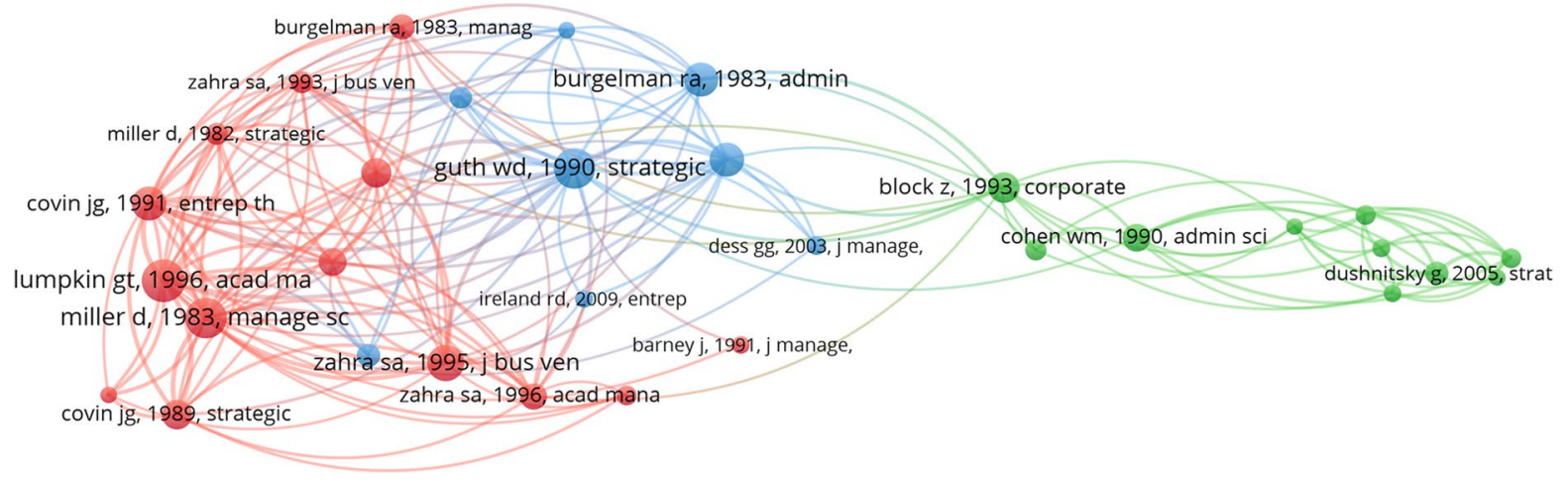

Fig. 1 Intellectual structure of corporate entrepreneurship research

the main definitions and issues in the field (Guth \& Ginsberg, 1990; Sharma \& Chrisman, 1999). In contrast, the articles at the right-hand side tend to be cited together and are not very connected to the rest of the literature. These articles on the right focus mostly on corporate venture capital, which appears as a separate topic within CE literature, and are published more often in strategy and management journals than in entrepreneurship ones (Dushnitsky \& Lenox, 2005; Wadhwa \& Kotha, 2006, among others).

\subsection{Content analysis}

Following previous research (Clark et al., 2014), in this section we focus on the main topics and their trends in the CE literature. This allows to see how the key concepts and ideas have changed and evolved over time (Volery \& Mazzarol, 2015).

The increase in the number of articles published in recent years has led to a wider number of topics studied. Emphasis has been placed on the different forms and dimensions of CE, such as: Corporate venture capital (Rind, 1981); International CE (Zahra \& Garvis, 2000); Corporate venturing (Zahra, 1996b); Social intrapreneurship (Kistruck \& Beamish, 2010); Franchising (Dada et al., 2012); Innovation based CE (Kelley et al., 2009; Wadhwa et al., 2016); or, Strategic renewal (Glaser et al., 2015; Zahra, 1993, 1996a). Previous research has highlighted the clarification of the different $\mathrm{CE}$ domains (and its definitions) as a key issue for the future understanding of this field (Kuratko et al., 2015). In addition, most theoretical models have also paid attention to the role of both antecedents and consequences of engaging in corporate entrepreneurial activity (Zahra, 1991). For instance, Antoncic and Hisrich (2001) present and test a model that studies the effect of a set of antecedents at different levels of analysis (organization and environment). Subsequently, they measure the effect of corporate entrepreneurial activity on firm growth and profitability. Similarly, Ireland et al. (2009) develop an integrative model of corporate entrepreneurship strategy that considers antecedents, elements and consequences of CE.

Overall, we develop a model (Fig. 2) that summarizes extant literature differentiating between 3 main areas: $\mathrm{CE}$ antecedents, $\mathrm{CE}$ dimensions, and $\mathrm{CE}$ consequences. This approach is consistent with previous literature (Antoncic \& Hisrich, 2001; Ireland et al., 2009; Kuratko et al., 2015; Zahra, 1991) and allows to provide a systematic content analysis as well as an organizing framework to analyze CE literature current status (Keupp \& Gassmann, 2009). The different clusters presented in Fig. 2 are the result of the analysis and coding of the articles analyzed. In particular, the analysis of the research objectives, findings and levels of analysis was particularly useful for creating and developing this model. Finally, the information in Fig. 2 was complemented with information from other literature reviews and theoretical articles to ensure our model considered and extended the knowledge generated in previous research (Corbett et al., 2013; Dess et al., 2003; Guth \& Ginsberg, 1990; Ireland et al., 2009; Kuratko et al., 2015; Minola et al., 2016, 2021; Narayanan et al., 2009; Phan et al., 2009; Sharma \& Chrisman, 1999). 


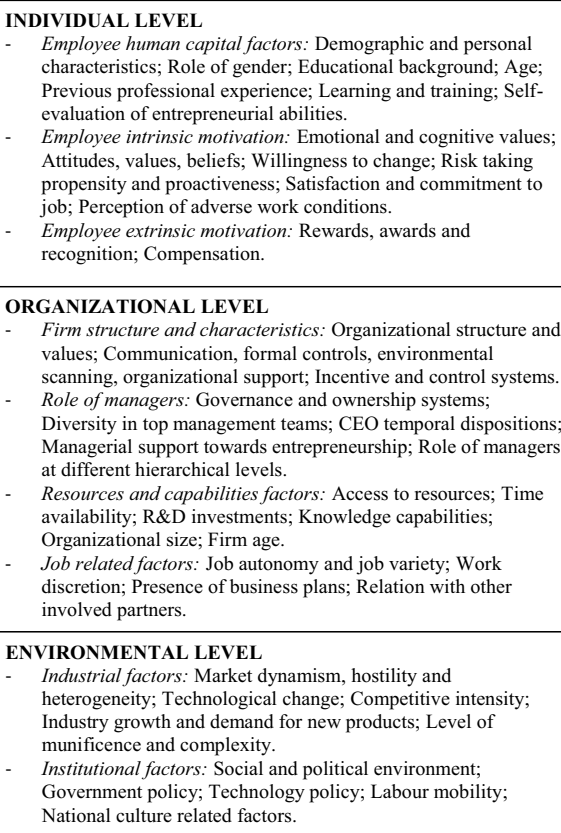

Fig. 2 Conceptual model for CE activity

\subsubsection{Antecedents}

Research has focused on which conditioning factors have an effect on the development of CE initiatives. The main objectives of the early studies (those published in the 1960s and 1970s) were to explain how to stimulate the development of CE activities (Westfall, 1969). Later, in the 1980s, the first papers on the antecedents of CE activity and on the compensation and incentive practices for venture managers were published (Block \& Ornati, 1987). In the 1990s, papers deepened analysis of the antecedents of CE activity (Zahra, 1991). Generally, researchers examined company related factors (i.e., Zahra, 1991, 1993), although some started taking into account the role of environmental factors (Tsai et al., 1991). Overall, the literature has highlighted at least three different types of factors at different levels that can influence CE: individual, company related and environmental. For instance, Guth and Ginsberg (1990) highlight the importance of strategic leaders for $\mathrm{CE}$ and explain the influence of the environment (competitive, technological, social and political) and of the organization (strategy, structure, process and values). Similarly, Antoncic and Hisrich (2001) differentiate explicitly between organizational (including person-related) and environmental factors. Other theoretical models such as Zahra (1991, 1993), or, Zahra et al. (2009) follow similar approaches by grouping the conditioning factors at these different levels of analysis.

At the individual level, literature has highlighted demographic and personal characteristics as a key factor for CE (Camelo-Ordaz et al., 2012). Specifically, emotional and cognitive factors (Biniari, 2012; Corbett \& Hmieleski, 2007) including attitudes, values and beliefs, have been repeatedly considered to play a crucial role in initiating and sustaining CE activities (Ireland et al., 2009; Turner \& Pennington, 2015). From this perspective, research has explained how having a willingness to change (Kellermanns \& Eddleston, 2006), a risk taking propensity (Heavey et al., 2009) or being satisfied and committed to your job (Akehurst et al., 2009) increase the likelihood of engaging in $\mathrm{CE}$ activity.

In addition, other aspects have also been considered to condition CE. Research has shown that 
different types of previous professional experiences increase the likelihood of engaging in $\mathrm{CE}$ initiatives (Dokko \& Gaba, 2012). Also, the self-evaluation of entrepreneurial abilities has been considered as an antecedent of CE (Martiarena, 2013). Special emphasis has been placed on the effect of compensation (Monsen et al., 2010; Wang et al., 2015), rewards, awards and recognition in motivating people to engage in CE (Burgers et al., 2009).

At the organizational level, one of the first antecedents studied was companies' organizational structure and values (Zahra, 1991) and issues such as communication, formal controls, environmental scanning or organizational support have been shown to have a positive effect on CE (Antoncic \& Hisrich, 2001). More recently, the literature highlights resource availability as one of the most important organizational antecedents and shows that access to resources is closely related to the firm's overall entrepreneurial orientation (Grande et al., 2011) and strategy (Zahra, 1991). From this perspective, time availability (Marvel et al., 2007) or knowledge capabilities (Maes \& Sels, 2014) are also relevant. In addition, the effect of factors such as financial resources, R\&D investments (Sahaym et al., 2010) or organizational size (Nason et al., 2015) have also been researched. However, the nature of the relationship between these specific resources and entrepreneurial activity has been subject to discussion among scholars. One stream of research argues that a bigger pool of such resources should facilitate the development of CE activities. Scholars suggest that having more resources or working in bigger companies may impede developing entrepreneurial activities because employees tend to be more risk averse because of bureaucracy and organizational processes tend to be more complex and rigid (Plambeck, 2012). Finally, researchers examined the association of a company's governance and ownership systems and its level of CE (Romero-Martínez et al., 2010; Zahra, 1996a; Zahra et al., 2000).

The different role of managers at different hierarchical levels has been studied (Radaelli $\&$ Sitton-Kent, 2016). From a top management team perspective, managers are considered to have multiple and critical roles in CE activity, mainly because they are centrally involved in the defining processes of both the corporate venturing and strategic renewal forms of CE (Kuratko
\& Audretsch, 2013). Further, attention has been given to the vital role that middle managers can have in creating an environment that encourages innovation and entrepreneurship (Wooldridge et al., 2008).

Antecedents at the environmental level of analysis have been less researched. Most studies focus on industry-related variables such as: the degree of market dynamism, hostility and heterogeneity (Zahra, 1991, 1993); technological change (Sahaym et al., 2010); competitive intensity (Basu et al., 2011); industry growth and demand for new products (Antoncic \& Hisrich, 2001); or the level of munificence and complexity (Simsek et al., 2007). Further, only a few authors have empirically examined the influence of national culture related factors on companies' entrepreneurial initiatives (Judge et al., 2015; Turro et al., 2016). Similarly, our research identified no empirical studies and only one theoretical article that study the effect of government policy on CE (Doh \& Pearce, 2004).

\subsubsection{Dimensions}

In the 1980s, the literature was mainly concerned with the organizational renewal process and the combination of resources necessary to commit to develop an innovative project (Burgelman, 1983a, 1983b; Pinchot, 1985; Schollhammer, 1982). Later, in the 1990s, CE was more clearly associated with the creation of new businesses within established companies (Bosma et al., 2013; Zahra, 1991). Similarly, during this decade some researchers made explicit use for the first time of some theoretical frameworks such as population ecology (Tsai et al., 1991) or the resource-based view (McGrath et al., 1994).

The beginning of the twenty-first century is associated with a much greater number of topics being studied, such as international CE (Zahra \& Garvis, 2000), CE in family firms (Kellermanns \& Eddleston, 2006) or the development of theoretical models explaining different areas of CE (Ireland et al., 2009). In addition, several studies focused on the differing nature of CE activities compared with those of independent entrepreneurship (e.g., Parker, 2011).

In recent years, the different dimensions that constitute the $\mathrm{CE}$ phenomenon have become more evident as researchers increasingly study them separately. However, the literature still does not 
agree completely on its main dimensions (Ireland et al., 2009). Based on the entrepreneurial orientation construct, researchers usually classify CE into three to five dimensions (Covin \& Slevin, 1991)new business venturing, product, service and process innovativeness, self-renewal and proactiveness (Guth \& Ginsberg, 1990; Lampe et al., 2020; Zahra, 1993) are the most common. Others, such as Phan et al. (2009), consider that innovation and corporate venturing activities, on the one hand, and renewal and the ability to compete and take risks, on the other, are two distinct but related phenomena. These activities are closely related to the strategic entrepreneurship concept, which has been defined by Hitt et al., (2001, p. 481) as "the integration of entrepreneurial (i.e., opportunity-seeking behavior) and strategic (i.e., advantage-seeking) perspectives in developing and taking actions designed to create wealth." Therefore, some previous research propose that CE entails two main activities. The first is a company's involvement in the creation of new businesses. The second is strategic entrepreneurship, which corresponds to a broader array of entrepreneurial initiatives which do not necessarily involve new businesses being added to the firm (Kuratko et al., 2011). In this regard, it has been argued that the main forms that strategic entrepreneurship can take are strategic renewal, sustained regeneration, domain redefinition, organizational rejuvenation and business model reconstruction (Kuratko et al., 2015; Pettit \& Crossan, 2020).

The corporate venturing dimension is the most researched (Narayanan et al., 2009; Zahra \& Hayton, 2008) and the literature usually differentiates between two types of corporate venturing activities: Externally directed corporate venturing units; and internally directed corporate venturing units which try to exploit business opportunities within the boundaries of the parent firm (Covin et al., 2021; Sharma \& Chrisman, 1999). In addition, a growing number of articles have studied the differences between independent (also known as, traditional or private) venture capital and corporate venture capital (Dushnitsky \& Shapira, 2010).

\subsubsection{Consequences}

The relationship between CE and firm performance has also attracted considerable research interest over the past four decades. In the late 1980s, researchers began studying the relationship between performance and engagement in CE activities (Miller et al., 1988) and during the 1990s, the positive effect of CE on firm performance became even more evident (Zahra, 1991). Overall, there is agreement that CE can renew a company's capabilities and increase its capacity to acquire and use new competencies that improve performance (Zahra et al., 2000). Indeed, Antoncic and Hisrich (2001, p. 504) state that "organizations that engage in intrapreneurial activities are expected to achieve higher levels of growth and profitability than organizations that do not."

Researchers agree that some CE initiatives have strategic objectives, while others pursue financial goals. From a strategic perspective, firms may engage in CE because of several benefits that include: learning, successful integration of a company's operations, improved responsiveness, successful standard setting (Narayanan et al., 2009) or acquiring new skills or technologies (Dushnitsky \& Lenox, 2005). However, research has primarily focused on the financial consequences of entrepreneurial activities (which may be easier to measure) and, therefore, there is a need to study the non-financial goals of CE initiatives (Zahra, 1991).

From a financial perspective, there is general agreement in the literature that $\mathrm{CE}$ has a positive effect on firm performance (Bierwerth et al., 2015; Zahra, 1991) by increasing the company's proactiveness and risk taking, and by promoting product, process, and service innovations (e.g., Lumpkin \& Dess, 1996; Walter et al., 2006). These capabilities allow the firm to improve its competitive position and can enable it to enter new industries in pursuit of profitability and growth (Clark et al., 2014; Zahra et al., 2000; Zahra, 1996a). CE has an effect on a firm's ability to compete and adapt to successfully perform in increasingly turbulent environments, by enabling the ongoing rejuvenation of product, market and strategic positions and the revitalization of knowledge and intellectual capital (Zahra et al., 1999). Thus, CE activities have become a key variable in explaining performance differences across firms (Heavey \& Simsek, 2013).

Building on key findings of the content analysis we have just presented, Fig. 2 provides a conceptual framework summarizing and synthesizing the most relevant concepts. 


\section{Emerging trends and avenues for future research}

In the light of our preceding analysis and discussion of the literature, in this section, we suggest an agenda for further research on $\mathrm{CE}$ antecedents, dimensions and consequences. We also outline limitations of our analysis.

\subsection{Corporate entrepreneurship antecedents}

The role of the institutional environment Studies that emphasize the organizational and individual levels of analysis have focused on issues such as organizational structure (Covin \& Slevin, 1991; Zahra, 1991), incentive and control systems (Sathe, 1985), managerial support towards entrepreneurial initiatives (Hornsby et al., 2002), personal traits and values (Antoncic \& Hisrich, 2001), or gender (Lyngsie \& Foss, 2017).

Yet, as noted, when studying which environmental factors can affect $\mathrm{CE}$, the emphasis is normally placed on industry related factors. Hence, other environmental or even institutional variables that could have a significant influence, such as culture or legal regulations have been less researched (Urbano et al., 2019).

To our knowledge, since the early work of Morris et al., (1993, 1994), few empirical papers have appeared analyzing the role of national culture related factors at a country (or specific region) level of analysis (Turro et al., 2014). Nevertheless, theoretical research has pointed out the importance that institutional variables could have for CE. For instance, Hornsby, Bloodgood, et al. (2013), p. 312) state that "it is important to consider how cultural factors may also influence the internal dynamics of the CE process." Some researchers have considered the companies' internal corporate culture and values (Antoncic \& Hisrich, 2001; Zahra, 1991; Zahra et al., 2009). Although internal corporate values may be affected by the more general (national) cultural setting, the literature considers it to be an organizational factor rather than an environmental one. Similarly, even though public policies may have a direct impact on the development of entrepreneurial initiatives (Gnyawali \& Fogel, 1994), there are very few papers on the role of government regulations in the CE field (Doh \& Pearce, 2004).
The above shortcomings are even more striking when we consider that the literature on independent entrepreneurship has repeatedly highlighted the impact of informal and formal institutional factors such as culture or regulations (Kreiser et al., 2002; Morris et al, 1994). Since national culture reinforces certain personal characteristics and penalizes others, these types of studies show how entrepreneurship differs from one national culture to another as some values favor entrepreneurial behavior more than others (Hayton et al., 2002). In addition, the literature suggests that regulations can also have a significant effect on entrepreneurship (Begley et al., 2005). For instance, inefficient government regulations in the economy may be perceived negatively by entrepreneurs and, hence, this may discourage them from starting new businesses (Djankov et al., 2002). Despite the appeal of such claims, we need to study them carefully in the context of CE.

An institutional perspective on CE would help delineate the effect of the environment on stimulating $\mathrm{CE}$ activities as well as its potential role as a moderator of the CE-company performance relationships. To gain a better appreciation of the nature and magnitude of this effect, it is necessary for future research to examine different dimensions of institutions such as labor laws, IP, extent of government regulations, among others. Separately and in combination these dimensions could shape managerial incentives which, in turn influence their decision time horizons, willingness to invest in $\mathrm{CE}$, and take the risks associated with various efforts needed to stimulate innovation and strategic renewal. Future research also needs to consider how the nature of the diversity of individuals' demographics and expertise interacts with institutional factors to facilitate or constrain CE. For example, while we have some evidence that more women on top management teams is associated with more CE (Lyngsie \& Foss, 2017), we have little understanding of how this might differ in institutional contexts with differing gender attitudes and roles. Similarly, there is an absence of the evidence on the impact on $\mathrm{CE}$ of other dimensions such as ethnic and religious diversity. This could be related to those studies that emphasize the relevance of the different entrepreneurial mindsets for $\mathrm{CE}$ activities, however, it remains unexplored (Kuratko et al., 2021). Previous research has already suggested that the role of the institutional environment for $\mathrm{CE}$ can be different between 
developing and developed countries, however, these findings have not been tested quantitatively (Hughes \& Mustafa, 2017).

Furthermore, the role of the business sector to which the company belongs has rarely been considered seriously when studying CE. Yet, a business sector has a fundamental influence on $\mathrm{CE}$ as it affects the rate of change of the competitive environment (Burgers et al., 2009). Further, with very few exceptions (Schildt et al., 2005), empirical research focuses upon the manufacturing sector. However, service sectors also develop CE activities which should be systematically studied. More generally, research is now emerging on the nature of the role and dimensions of the ecosystem for the start-up entrepreneurship (e.g., Autio et al., 2018). However, we know little about how the ecosystem for CE may be distinctive and the research agenda in this space would appear to be a potentially rich one.

Methodological approaches Despite the literature agreeing on the multilevel nature of $\mathrm{CE}$ antecedents (Antoncic \& Hisrich, 2001; Ireland et al., 2009; Zahra, 1991), our search identified few studies using a multilevel regression technique (or any other type of hierarchical linear modelling method) (e.g., Behrens \& Patzelt, 2016; Kang et al., 2016). Hence, future research could exploit this methodological approach to better establish the contributions of $\mathrm{CE}$ to firm performance. The potential importance of individuals at different levels in the organization, from nonmanagerial employees upward, suggests scope for future studies to develop linked employee-managerial-organization-databases. Such cross-level analyses may go some way to exploring the gap in understanding of the microfoundations of a firm's systematic organizational capability for corporate entrepreneurship. Developing such a capability may require firms to combine individual-level entrepreneurial roles and firm-level entrepreneurial processes (Salvato et al., 2009).

Hierarchical levels and compensation The role of first level managers has been less researched as literature focuses mainly on middle and top management. However, some authors have suggested that bottomup processes are important for $\mathrm{CE}$ and that first level managers play a key role in this process (Hornsby et al., 2009). Further, in some sectors and firms, non-managerial employees through their day-to-day interaction with the market may have access to the kind of information that enables them to identify new entrepreneurial opportunities. Similarly, the effects of managers' and employees' compensation (regardless of the hierarchical level) on CE have not been studied in depth (Hornsby et al., 2002). Issues such as which kind of compensation methods should be used with corporate entrepreneurs to foster their entrepreneurial initiatives need further examination. Moreover, although the nature of compensation for management has already been considered important for CE since it can influence time horizons and strategic behaviors (Block \& Ornati, 1987; Phan et al., 2009), recent changes in corporate ownership and funding of innovation and other $\mathrm{CE}$ activities make it essential to revisit these contributions to $\mathrm{CE}$.

\subsection{Corporate entrepreneurship dimensions}

Independent entrepreneurship vs $\mathbf{C E}$ There have recently been some attempts to compare $\mathrm{CE}$ and independent entrepreneurship as two separate phenomena (instead of CE being a sub-field of entrepreneurship) (Stam, 2013). Hence, the antecedents that make individuals choose between becoming self-employed or corporate entrepreneurs have been well documented (Hellman, 2007; Kacperczyk, 2012). However, several issues remain unexplored. For instance, a better understanding of the design of contracts and work environments that minimize the risk that the employees seek to avoid by starting their own ventures, could generate interesting insights (Parker, 2011). In addition, while both independent entrepreneurship and $\mathrm{CE}$ are important drivers of economic growth, the net effect of both types of ventures is not clear. Therefore, further studies could investigate and compare the performance of internal versus external ventures to assess better their weights and impacts on economic growth (Kacperczyk, 2012).

CE forms Our results show that, to date, few studies have examined the dissimilarities among the different forms of CE (for an exception, see Verbeke et al., 2007). However, since entrepreneurial activities are essential for companies to adapt to environmental changes, a greater appreciation of the factors that determine such activities should have both theoretical 
and practical implications (Zahra et al., 1999). The lack of studies in this particular area reflects a lack of consensus about the main forms of entrepreneurship in established companies, which is surprising given the large volume of research on CE. Understanding these forms will help in establishing their usefulness to companies and the conditions leading to their success.

Opportunity identification process Relatedly, few studies have explored the opportunity identification side of the different CE activities and the subsequent exploitation of these opportunities (Bloodgood et al., 2015; Foss et al., 2013). This is in contrast to literature on independent entrepreneurship where the fundamental importance of the opportunity identification process has been extensively highlighted (Shane, 2000). Given recent debates in the independent entrepreneurship literature about whether opportunities are created or discovered (Alvarez \& Barney, 2019), exploration of whether and how the CE context differs in this respect seems warranted. Thus, it may also be fruitful to study the extent to which internal decision-making processes in corporations affect the nature of opportunities identified and pursued because they maybe more attuned to dealing with assessing risk rather than uncertainty. In this regard, O'Connor and Rice (2001) explore the opportunity identification process for technological breakthrough innovations, however, their multiple case study analysis is limited to large, technology-intensive, established firms. Therefore, further research focusing on other aspects and contexts is necessary.

Life cycle and $\mathbf{C E}$ The life cycle dimension of CE activities has not been sufficiently studied, highlighting the need for further research on the topic. This is an important gap in understanding the processes by which CE activities emerge, develop and decline and their impact on corporate performance is likely to vary with these changes. Understanding this life cycle may clarify how the form of CE might change with increased organizational experience and time (Guerrero et al., 2021). Further, understanding the relationship between different life cycles (industry, company, segments or products) and CE could provide significant implications for future research (Hoy, 2006). Further, studying firm and organizational life cycles might help researchers identify the gamut of
CE activities that unfold over time and their implications for organizational success and adaptation.

Ownership and governance In the area of governance systems and property rights, findings from prior studies on the role of ownership in different types of CE are fragmentary. Nason et al. (2015) only cover ownership in the sense that they explore private SMEs versus large listed corporations. But private ownership is more nuanced and includes family firms, venture capital and private equity backed firms, and even socially owned and hybrid enterprises that may engage in CE related activities (Zahra et al., 2009). Amess et al. (2016), Wright et al. (1992) and Zahra (1995) consider some initial aspects of CE in private equity owned firms, while Chrisman et al. (2015) consider CE in the form of innovation in family firms. As a result, more systematic analysis comparing different types of ownerships is needed (Hale \& Woronkowicz, 2020). We also know that even within different types of ownership, organizations may have different goals (Kotlar et al., 2018) which would suggest a need to consider $\mathrm{CE}$ in the context of organizational goals.

The role of size: Large Corporation and SME Even though some authors have explained that $\mathrm{CE}$ can be relevant for large corporations as well as small and medium sized enterprises (Carrier, 1994; Zahra et al., 2000), there are few studies focusing on the different sizes of corporate entrepreneurial projects (an exception is Nason et al., 2015). There is little information on antecedents of and the extent to which major and minor intrapreneurial initiatives have the same characteristics. We also know little about their contribution to the general economy and firm performance. Overall, there seems to be a need for further studies focusing on the nature of CE (e.g., focus, goals, form and size) among large, established companies and SMEs (Zahra et al., 2000).

Complexity of CE In addition to the size of CE projects, complexity is also a dimension of CE. Complexity may relate to technological aspects but also to the complexity of the markets to be served and the services to be provided. Such complexity may call for collaboration among organizations. Beyond the extensive literature on joint ventures and alliances between corporations, collaborations may involve corporations and universities, governmental 
agencies, not-for-profit organizations, individual entrepreneurs, etc. For example, co-creation arrangements, either focused on particular projects or longer term linkages, have emerged recently to engage in $\mathrm{CE}$ activities that combine social and commercial goals (DeSilva \& Wright, 2019). At present, we have very limited analysis of the motivations, organizational forms, processes and outcomes of such CE activities.

\subsection{Corporate entrepreneurship consequences}

Performance measures Our analyses also highlight shortcomings and areas to develop further research in terms of CE consequences. Studies that examine the relation between $\mathrm{CE}$ and firm financial performance typically use measures such as return on investment (Zahra, 1991), return on sales (Zahra, 1993), return on equity (Zahra \& Hayton, 2008), market share gain (Bojica \& Fuentes, 2012) or cash flow (Miller et al., 1988). Previous literature has already highlighted the difficulties of measuring performance in organizational studies, particularly among new ventures because even successful start-ups often do not reach profitability for a long period of time (Tsai et al., 1991). Hence, some researchers have explained the benefits of using other types of performance measures (Miller et al., 1991). Similarly, from a CE consequences perspective, we have limited understanding of the drivers that lead to project failure and to the termination of CE activities (Behrens \& Patzelt, 2016; Shepherd et al., 2009). In addition, and related to the points above regarding types of ownership and goal variety, studies of the consequences of $\mathrm{CE}$ also need to explore social as well as financial, and economic outcomes in relation to ownership goals. Moreover, prior research ignores the specific goals companies pursue when they measure the overall impact of CE activities, failing to delineate where particular CE efforts influence specific performance goals and criteria (Kreiser et al., 2021).

\section{CE consequences and cross-cultural}

research Another area for further study relates to the focus of most prior studies on the financial outcomes of developing CE activities in US firms. Few studies focus on European companies (Bojica \& Fuentes, 2012; Walter et al., 2006), or explicitly adopt a cross country comparison between the US and elsewhere (Antoncic \& Hisrich, 2001) and only one examines this phenomenon using global data (Zahra \& Hayton, 2008). From this view, some authors have considered that cross-cultural research has the potential to expand the concepts and theories that have been developed in a single cultural setting (Antoncic \& Hisrich, 2001). For instance, Hills and LaForge (1992) stress the importance of conducting entrepreneurship research in an international context as some authors observe that entrepreneurial initiatives cannot be understood without attention to the context in which they take place. The review by Bierwerth et al (2015) cites studies on CE in Austria, Canada, China, Ireland, Netherlands, Poland, Portugal, South Africa, Taiwan, and Turkey, among others. This growing interest in CE worldwide reflects its importance for stimulating innovation, risk taking, competitive aggressiveness which are essential for success in today's intensely competitive global markets. While true of economies the world over, CE is especially relevant to companies in emerging economies where privatization efforts have been widespread aiming to stimulate entrepreneurship. Companies in these economies also seek to catch up technologically with their counterparts from advanced economies. State owned enterprises in these countries are also facing tough competition for foreign entrants as well as local start-ups, making CE a key means for these companies' adaptation. Recent shifts associated with the resurgence of state capitalism may also warrant a reassessment of how CE is measured (Grossman et al., 2016). State owned enterprises may differ in their goals and objectives, the expectations of their stakeholders, their life-cycle phases, their time horizons and the involvement of their owners in boards of directors that can help facilitate or constrain CE rather than just providing a monitoring function. These differences may have implications for the nature and use of CE. For example, to what extent is CE driven by financial and economic objectives, or social and political objectives, and what conflicts arise? Further, how do these conflicts affect CE's success? Clearly, these issues deserve careful study and analysis.

The lack of good databases poses challenges for conducting cross-cultural and international research on $\mathrm{CE}$ - most studies collect their own data (i.e., Maula et al., 2009). Among the secondary sources of information, the Profit Impact of Marketing Strategy (PIMS) start up database (employed mostly at the beginning of the 1990s) and the VentureXpert database (Park \& Steensma, 2012) are the most widely employed. 
Funding and CE There are also very few examples of articles that examine the consequences of different types of funding for CE (Park \& Steensma, 2012), especially across countries and industries despite the acknowledged structural differences that might exist in this regard. This could be explained because researchers tend to assume that companies fund these activities; however, this is not always the case (Dushnitsky \& Shapira, 2010). Therefore, future research could deepen more specifically the outcomes and consequences of different types of CE funding (e.g., inhouse vs outside), given that managers' incentives could potentially determine their preferences for particular types of venturing and other CE activities.

Table 5 summarizes our discussion by presenting some examples of future research questions on CE. It also provides a synthesis of topics that the literature has considered to be relevant but that have not been studied in detail. The results of our systematic literature review show that the increase in the number of articles published in the last decade has led to additional research questions and relevant topics to be explored. Moreover, some areas have been significantly more researched than others. Overall, despite the progress made to date, there are many important topics that require further research. With the globalization of the world economy, CE researchers have a golden opportunity to examine differences (and similarities) across countries and document how CE activities of different types could impact companies' competitiveness, ability to adapt, and engage in continuous innovation and renewal.

\section{Conclusion}

Despite the recent increase in the number of publications on $\mathrm{CE}$, there are few recent systematic literature reviews focusing on the topic. Offering such a review, this research provides information on the content and evolution of CE. Specifically, 310 papers published in the top and highly cited journals in the business, management and entrepreneurship fields are examined. Our review contributes to the literature by providing a complete analysis of the current state of the art of research in this field. The review highlights the types of articles, theoretical frameworks and quantitative and qualitative methods used. It also provides a detailed analysis of how the main topics studied have evolved over time. This enabled us to identify the main categories (CE antecedents, $\mathrm{CE}$ dimensions, and $\mathrm{CE}$ consequences) and subcategories in this field. The changing scope of the CE concept over the decades has helped to enlarge the research agenda. The emerging trends and under researched areas of $\mathrm{CE}$ that we have identified open up further avenues for scholarly exploration. Clearly, there is a great deal of interest in CE and this interest is global, suggesting the need for more careful investigations of its international dimensions and strategic relevance.

As with all studies, our review also has several limitations that offer opportunities for further research. First, in line with many other review articles, our focus is on the main journals in the management and entrepreneurship fields that involve robust review procedures and are likely to include CE work. This approach is consistent with previous literature (Busenitz et al., 2014; Marvel et al., 2016) and allowed us to focus on outlets where CE has a central role, however, this implied not searching in journals that focus specifically on fields such as innovation or international business. Similarly, studies published elsewhere in conference proceedings and doctoral theses have been excluded to avoid overlap as they are often the first step before publication in a journal and also to ensure that we include the most rigorous and definitive version. Second, as is generally recognized, citation, and co-citation techniques have some inherent flaws. When compiling citations, it is impossible to distinguish their objectives. Authors may refer to other articles to explain, justify or build their own ideas. However, citations may be used for other purposes such as to criticize another author's work or to mention one's own articles, or are simply gratuitous citations. While this may potentially inflate some aspects of the citations analysis, it is less likely to impact the scope of the themes we have presented. Third, although we have adopted a broad definition of CE (Sharma and Chrisman (1999); Antoncic and Hisrich (2001), our review did not incorporate the study of the strategic entrepreneurship concept as this was beyond our scope. Although the fields of strategic management and entrepreneurship have developed independently (Ireland et al., 2003), they both focus on "how firms adapt to environmental change and exploit opportunities created by uncertainties and discontinuities in the creation of wealth" (Hitt 


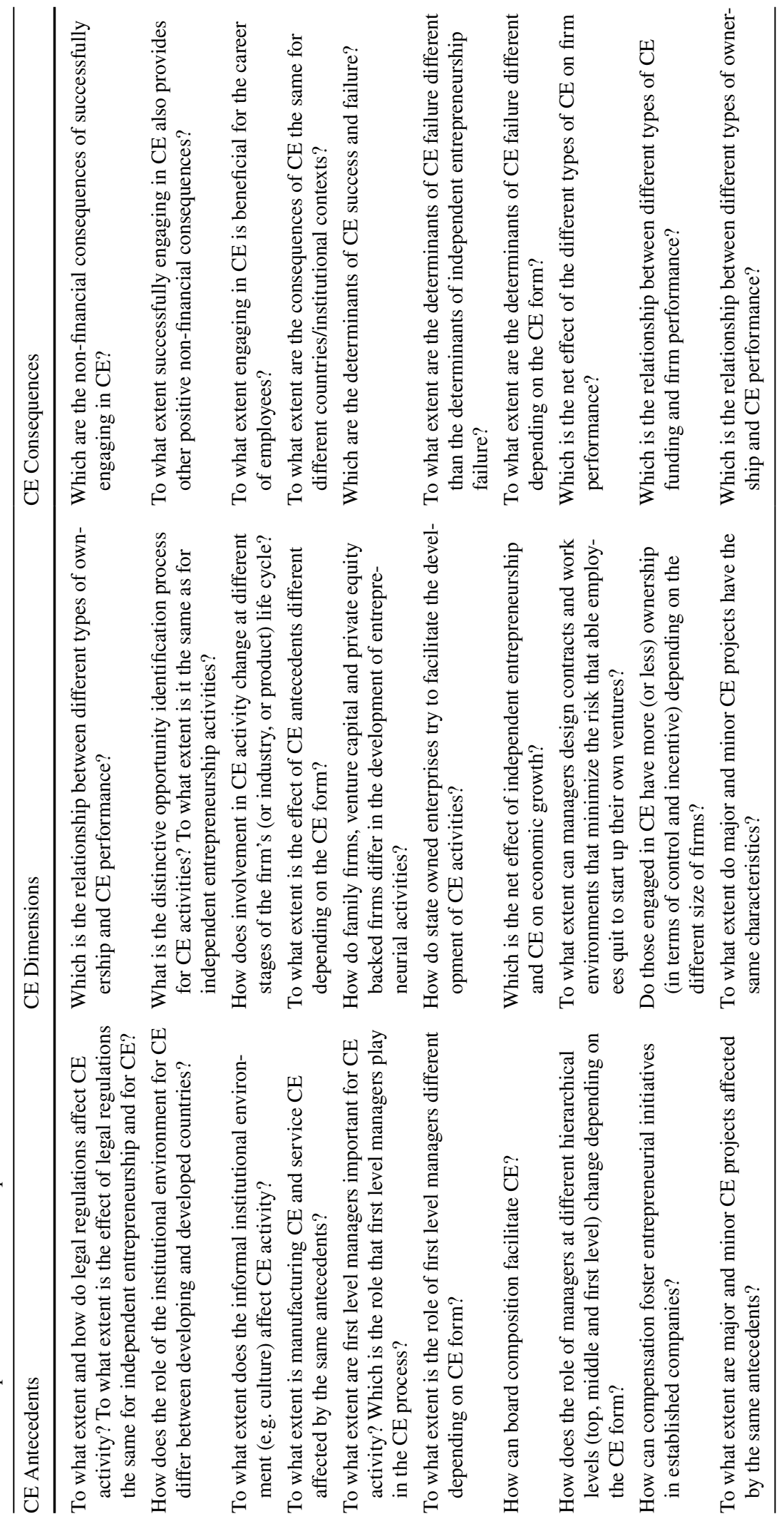


et al., 2001; p. 480). Hence, as shown in Fig. 2, future research should integrate both approaches as some entrepreneurship and innovation activities fit within the definition of both concepts. For the same reason, other overlapping fields such as, organizational creativity, organizational ambidexterity or entrepreneurial orientation were also excluded from the search terms. Future research could deepen on the relation with these neighboring fields.

Acknowledgements Our co-author, Mike Wright, sadly passed away before this article was published. He is sorely missed. David Urbano acknowledges the financial support from the projects ECO2017-87885-P (Spanish Ministry of Economy \& Competitiveness) and 2017-SGR-1056 (Economy \& Knowledge Department, Catalan Government), and ICREA under ICREA Academia programme.

Funding Open Access Funding provided by Universitat Autonoma de Barcelona.

Open Access This article is licensed under a Creative Commons Attribution 4.0 International License, which permits use, sharing, adaptation, distribution and reproduction in any medium or format, as long as you give appropriate credit to the original author(s) and the source, provide a link to the Creative Commons licence, and indicate if changes were made. The images or other third party material in this article are included in the article's Creative Commons licence, unless indicated otherwise in a credit line to the material. If material is not included in the article's Creative Commons licence and your intended use is not permitted by statutory regulation or exceeds the permitted use, you will need to obtain permission directly from the copyright holder. To view a copy of this licence, visit http://creativecommons.org/licenses/by/4.0/.

\section{Appendix}

List of articles included in the study (ranked by number of articles published in each of the selected journals)

\section{Journal of Business Venturing:}

Abetti (1997); Allen and Hevert (2007); Antoncic and Hisrich (2001); Arzubiaga et al. (2018); Badguerahanian and Abetti (1995); Basu et al. (2011); Belderbos et al. (2018); Block and Ornati (1987); Bradley et al. (2011); Brazeal (1993); Browder et al. (2019); Brundin et al. (2008); Burgers et al. (2009); Covin et al. (1999); Covin et al. (2015); Covin et al. (2020); DeSarbo et al. (1987); Dushnitsky and Lenox (2006); Filatotchev et al. (1999); Green et al. (2008);
Gupta et al. (2004); Gupta and Sapienza (1992); Hill and Birkinshaw (2008); Hornsby et al. (2002); Hornsby et al. (2009); Janney and Dess (2006); Jones et al. (2011); Kang et al. (2016); Kelley et al. (2009); Lin and Lee (2011); MacMillan and Day (1987); Maula et al. (2009); McDougall et al. (1992); McGrath (1995); McGrath et al. (1994); Miller et al. (1989); Miller et al. (1991); Miller et al. (1988); Ohe et al. (1992); Park and Kim (1997); Parker (2011); Patzelt et al. (2020); Patzelt et al. (2021); Pearce et al. (1997); Phan et al. (2009); Plambeck (2012); Ravasi and Turati (2005); Rigtering et al. (2019); Sahaym et al. (2009); Shankar and Shepherd (2019); Shepherd et al. (2009); Shrader and Simon (1997); Siegel et al. (1988); Sorrentino and Williams (1995); Srivastava and Lee (2005); Sykes (1986); Sykes (1990); Sykes (1992); Sykes and Block (1989); Sykes and Dunham (1995); Thornhill and Amit (2000); Tsai et al. (1991); Van de Vrande et al. (2009); Wadhwa et al. (2016); Waldkirch et al. (2021); Walter et al. (2006); Weber and Weber (2011); Westhead and Wright (1998); Wincent et al. (2014); Yang et al. (2009); Zahra (1991); Zahra (1993); Zahra (1995); Zahra (1996a, 1996b); Zahra and Covin (1995); Zahra and Garvis (2000); Zahra and Hayton (2008); Zahra et al. (2009).

\section{Entrepreneurship Theory and Practice:}

Biniari (2012); Block et al. (2019); Borch et al. (2021); Corbett and Hmieleski (2007); Covin and Lumpkin (2011); Covin and Miles (1999); Covin and Miles (2007); Covin and Miller (2014); Covin and Wales (2019); Covin et al. (2018); De Clercq et al. (2016); Dess et al. (1999); Doughery (1995); Eddleston et al. (2010); Fang et al. (2021); Fini et al. (2012); Finkle (2012); Garret and Covin (2015); Heller (1999); Hornsby et al. (1993); Hornsby et al. (1999); Hoy (2006); Hunt et al. (2019); Ireland et al. (2009); Jennings and Young (1990); Judge et al. (2015); Keil et al. (2010); Kellermanns and Eddleston (2006); Kistruck and Beamish (2010); Kotlar and Sieger (2019); Kreiser et al. (2020); Kuratko et al. (2005); Lampe et al. (2020); Marvel et al. (2007); Miles and Covin (2002); Monsen et al. (2010); Riar et al. (2021); Schild et al. (2005); Sharma and Chrisman (1999); Soleimanof et al. (2019); Titus Jr and Anderson (2018); Titus Jr et al. (2020); Uzuegbunam et al. (2019); Van de Vrande and Vanhaverbeke (2013); Verbeke et al. (2007); Vozikis et al. (1999); Yiu and Lau (2008). 


\section{Small Business Economics:}

Adachi and Hisada (2017); Akehurst et al. (2009); Amoroso et al. (2017); Audretsch (2015); Audretsch et al. (2015); Ben Arfi and Hikkerova (2019), Bertoni et al. (2013); Bierwerth et al. (2015); Biniari et al. (2015); Bloodgood et al. (2015); Braune et al. (2021); Braunerhjelm et al. (2018); Byrne et al. (2016); Cantner et al. (2020); Covin et al. (2021); Crawford and Kreiser (2015); Cruz and Nordqvist (2012); Cucculelli and Bettinelli (2015); Cucculelli and Peruzzi (2020); Cumming et al. (2008); Douglas and Fitzsimmons (2013); Fryges and Wright (2014); Glaser et al. (2015); Garrett and Holland (2015); Guerrero et al. (2019); Hale and Woronkowicz (2020); Iacobucci and Rosa (2005); Kearney and Morris (2015); Kellermanns et al. (2012); Kreiser et al. (2021); Kuratko et al. (2015); Kuratko et al. (2015); Martiarena (2013); Nason et al. (2015); Stam (2013); Turner and Pennington (2015); Useche and Pommet (2020); Zahra (2015); Zellweger and Sieger (2012).

\section{Strategic Management Journal:}

Ahuja and Lampert (2001); Alvarez-Garrido and Dushnitsky (2016); Barringer and Bluedorn (1999); Birkinshaw (1997); Boone et al. (2019); Burgers and Covin (2016); Ceccagnoli et al. (2018); Deichmann and Jensen (2018); Dushnitsky and Lenox (2005); Dushnitsky and Shapira (2010); Dushnitsky and Shaver (2009); Gaba and Dokko (2016); Garud and Van de ven (1992); Guth and Ginsberg (1990); Kannan-Narasimhan and Lawrence (2018); Keil et al. (2008); Kuratko et al. (1990); Larrañeta et al. (2014); Nielsen et al. (1985); Park and Steensma (2012); Pettit and Crossan (2019); Rind (1981); Schendel (1990); Shortell and Zajac (1988); Stopford and Baden-Fuller (1994); Yang et al. (2014).

\section{Journal of Small Business Management:}

Bettinelli et al. (2017); Bojica et al. (2017); Brumana et al. (2017); de Lange and Valliere (2020); Gentry et al. (2013); Hakala et al. (2016); Hughes and Mustafa (2017); Johnson (2012); Kim et al. (2018); Kim et al. (2021); Kuratko et al. (2021); Ma and Huang (2016); Maes and Sels (2014); Moreno and Munuera (2016); Naldi et al. (2015); Noyes et al. (2014); Park et al. (2019); Randolph et al. (2017); Simba and Thai (2019); Simon et al. (2002); Swoboda and Olejnik (2016).

\section{Journal of Management:}

Anderson et al. (2014); Dess et al. (2003); Drover et al. (2017); Engelen et al. (2015); Engelen et al. (2016); Hill and Birkinshaw (2014); Jennings and Lumpkin (1989); Jones and Butler (1992); Keupp and Gassmann (2009); Kim et al. (2019); Lengnick (1992); Lyon et al. (2000); Morris et al. (1993); Rosenbusch et al. (2013); Russell and Russell (1992); Shepherd et al. (2014); Shepherd et al. (2019); Titus Jr et al. (2017); Wooldridge et al. (2008); Zahra et al. (2000).

\section{Strategic Entrepreneurship Journal:}

Basu et al. (2016); Cabral et al. (2020); Di Lorenzo and Van de Vrande (2019); Dushnitsky and Lavie (2010); Eckhardt et al. (2018); Gaba and Bhattacharya (2012); Hill et al. (2009); Hinkler et al. (2010); Huang and Madhavan (2020); McGrath (2015); Minola et al. (2016); Mohammadi and Khashabi (2020); Park and Steensma (2013); Simsek and Heavy (2011); Smith and Shah (2013); Souitaris and Zerbinati (2014); Van Ness and Seifert (2016); Wang and Wan (2013); Weber et al. (2016); Zahra (2016).

\section{Journal of Management Studies:}

Alt and Craig (2016); Ambos and Tatarinova (2021); Chirico et al. (2021); De Massis et al. (2021); Dimov and Gedajlovic (2010); Doh and Pearce (2004); Fang et al. (2021); Haynes et al. (2015); Heavy et al. (2009); Keil (2004); Keil et al. (2008); Minola et al. (2021); Prugl and Spitzley (2021); Raitis et al. (2021); Ramirez-Pasillas et al. (2021); Simsek et al. (2007); Simsek et al. (2015); Teng (2007).

\section{International Small Business Journal:}

Camelo et al. (2012); Dada and Fogg (2016); Dada et al. (2010); Fini and Toschi (2016); Gupta and Batra (2016); Messeghem (2003); Shu et al. (2020); Thorgren et al. (2012); Wales et al. (2013); Wales et al. (2015); Yu et al. (2019); Zahra et al. (2014).

\section{Academy of Management Journal:}

Chin et al. (2021); Bae and Lee (2021); Dokko and Gaba (2012); Gaba and Meyer (2008); Ling et al. (2008); Souitaris et al. (2012); Wadhwa and Kotha (2006); Westfall (1969); Zahra (1996a, 1996b).

\section{Entrepreneurship and Regional Development:}

Casillas and Moreno (2010); Fayolle et al. (2010); Grande et al. (2011); Herbane (2019); Kemelgor (2002); Marchisio et al. (2010); Nordqvist and Melin (2010); Salvato et al. (2010); Turro et al. (2016). 


\section{Administrative Science Quarterly:}

Burgelman (1983a, 1983b); Chen and Nadkarni (2017); Kacperczyk (2012); Pahnke et al. (2015); Pontikes (2012).

\section{Management Science:}

Bhardwaj et al. (2006); Burgelman (1983a, 1983b); de Bettignies and Chemla (2008); Miller (1983).

Journal of International Business Studies:

Morris et al. (1994); Yiu et al. (2007).

\section{References}

Ahuja, G., \& Morris Lampert, C. (2001). Entrepreneurship in the large corporation: A longitudinal study of how established firms create breakthrough inventions. Strategic Management Journal, 22(6-7), 521-543. https://doi.org/ 10.1002/smj.176

Akehurst, G., Comeche, J. M., \& Galindo, M. A. (2009). Job satisfaction and commitment in the entrepreneurial SME. Small Business Economics, 32(3), 277-289. https://doi. org/10.1007/s11187-008-9116-Z

Alvarez, S., \& Barney, J. (2019). Has the Concept of Opportunities Been Fruitful in the Field of Entrepreneurship? Academy of Management Perspectives, 34(3), 300-310. https://doi.org/10.5465/amp.2018.0014

Amess, K., Stiebale, J., \& Wright, M. (2016). The impact of private equity on firms' patenting activity. European Economic Review, 86, 147-160. https://doi.org/10. 1016/j.euroecorev.2015.08.013

Anderson, N., Potočnik, K., \& Zhou, J. (2014). Innovation and creativity in organizations: A state-of-the-science review, prospective commentary, and guiding framework. Journal of Management, 40(5), 1297-1333. https://doi.org/ $10.1177 / 0149206314527128$

Antoncic, B., \& Hisrich, R. D. (2001). Intrapreneurship: Construct refinement and cross-cultural validation. Journal of Business Venturing, 16(5), 495-527. https://doi.org/ 10.1016/S0883-9026(99)00054-3

Autio, E., Nambisan, S., Thomas, L., \& Wright, M. (2018). Digital affordances, spatial affordances, and the genesis of entrepreneurial ecosystems. Strategic Entrepreneurship Journal, 12(1), 72-95. https://doi.org/10.1002/sej.1266

Basu, S., Phelps, C., \& Kotha, S. (2011). Towards understanding who makes corporate venture capital investments and why. Journal of Business Venturing, 26(2), 153-171. https://doi.org/10.1016/j.jbusvent.2009.07.001

Begley, T. M., Tan, W., \& Schoch, H. (2005). Politico-economic factors associated with interest in starting a business: A multi-country study. Entrepreneurship Theory and Practice, 29(1), 35-55. https://doi.org/10.1111/j. 1540-6520.2005.00068.x

Behrens, J., \& Patzelt, H. (2016). Corporate entrepreneurship managers' project terminations: Integrating portfoliolevel, individual-level, and firm-level effects. Entrepreneurship Theory and Practice, 40(4), 815-842. https:// doi.org/10.1111/etap.12147
Bettinelli, C., Sciascia, S., Randerson, K., \& Fayolle, A. (2017). Researching entrepreneurship in family firms. Journal of Small Business Management, 55(4), 506-529. https://doi.org/10.1111/jsbm.12347

Bierwerth, M., Schwens, C., Isidor, R., \& Kabst, R. (2015). Corporate entrepreneurship and performance: A metaanalysis. Small Business Economics, 45(2), 255-278. https://doi.org/10.1007/s11187-015-9629-1

Biniari, M. G. (2012). The emotional embeddedness of corporate entrepreneurship: The case of envy. Entrepreneurship Theory and Practice, 36(1), 141-170. https://doi. org/10.1111/j.1540-6520.2010.00437.x

Birkinshaw, J. (1997). Entrepreneurship in multinational corporations: The characteristics of subsidiary initiatives. Strategic Management Journal, 18(3), 207-229. https://doi. org/10.1002/(SICI) 1097-0266(199703)18:3\%3C207:: AIDSMJ864\%3E3.0.CO;2-Q

Block, Z., \& Ornati, O. A. (1987). Compensating corporate venture managers. Journal of Business Venturing, 2(1), 41-51. https://doi.org/10.1016/0883-9026(87)90018-8

Bloodgood, J. M., Hornsby, J. S., Burkemper, A. C., \& Sarooghi, H. (2015). A system dynamics perspective of corporate entrepreneurship. Small Business Economics, 45(2), 383-402. https://doi.org/10.1007/ s11187-015-9634-4

Bojica, A. M., \& Fuentes, M. D. M. (2012). Knowledge acquisition and corporate entrepreneurship: Insights from Spanish SMEs in the ICT sector. Journal of World Business, 47(3), 397-408. https://doi.org/10.1016/j.jwb.2011. 05.007

Bosma, N., Wennekers, S., Guerrero, M., Amorós, J.E., Martiarena, A., \& Singer S. (2013). Global Entrepreneurship Monitor: Special report on entrepreneurial employee activity, GERA.

Burgelman, R. A. (1983a). A process model of internal corporate venturing in the major diversified firm. Administrative Science Quarterly, 28(2), 223-244. https://doi.org/ $10.2307 / 2392619$

Burgelman, R. A. (1983b). Corporate entrepreneurship and strategic management: Insights from a process study. Management Science, 29(12), 1349-1364. https://doi. org/10.1287/mnsc.29.12.1349

Burgers, J. H., Jansen, J. J., Van den Bosch, F. A., \& Volberda, H. W. (2009). Structural differentiation and corporate venturing: The moderating role of formal and informal integration mechanisms. Journal of Business Venturing, 24(3), 206220. https://doi.org/10.1016/j.jbusvent.2009.01.006

Busenitz, L. W., Plummer, L. A., Klotz, A. C., Shahzad, A., \& Rhoads, K. (2014). Entrepreneurship research (19852009) and the emergence of opportunities. Entrepreneurship Theory and Practice, 38(5), 981-1000. https://doi. org/10.1111/etap.12120

Camelo-Ordaz, C., Fernández-Alles, M., Ruiz-Navarro, J., \& Sousa-Ginel, E. (2012). The intrapreneur and innovation in creative firms. International Small Business Journal, 30(5), 513-535. https://doi.org/10.1177/0266242610 385396

Carrier, C. (1994). Intrapreneurship in large firms and SMEs: A comparative study. International Small Business Journal, 12(3), 54-61. https://doi.org/10.1177/0266242694 123005 
Chrisman, J., Chua, J., De Massis, A., Frattini, F., \& Wright, M. (2015). The ability and willingness paradox in family firm innovation. Journal of Product Innovation Management, 32(3), 310-318. https://doi.org/10.1111/jpim. 12207

Clark, T., Wright, M., Iskoujina, Z., \& Garnett, P. (2014). JMS at 50: Trends over Time. Journal of Management Studies, 51(1), 19-37. https://doi.org/10.1111/joms.12040

Corbett, A. C., \& Hmieleski, K. M. (2007). The conflicting cognitions of corporate entrepreneurs. Entrepreneurship Theory and Practice, 31(1), 103-121. https://doi.org/10. 1111/j.1540-6520.2007.00165.x

Corbett, A., Covin, J. G., O’Connor, G. C., \& Tucci, C. L. (2013). Corporate entrepreneurship: State-of-the-art research and a future research agenda. Journal of Product Innovation Management, 30(5), 812-820. https://doi. org/10.1111/jpim.12031

Cottrill, C. A., Rogers, E. M., \& Mills, T. (1989). Co-citation analysis of the scientific literature of innovation research traditions: Diffusion of innovations and technology transfer. Science Communication, 11(2), 181-208. https://doi. org/10.1177/107554708901100204

Covin, J. G., \& Lumpkin, G. T. (2011). Entrepreneurial orientation theory and research: Reflections on a needed construct. Entrepreneurship Theory and Practice, 35(5), 855-872. https://doi.org/10.1111/j.1540-6520.2011. 00482.x

Covin, J. G., \& Slevin, D. P. (1991). A conceptual model of entrepreneurship as firm behaviour. Entrepreneurship Theory and Practice, 16(1), 7-25. https://doi.org/10. 1177/104225879101600102

Covin, J. G., Garrett, R. P., Kuratko, D. F., \& Bolinger, M. (2021). Internal corporate venture planning autonomy, strategic evolution, and venture performance. Small Business Economics, 56, 293-310. https://doi.org/10.1007/ s11187-019-00220-2

Dada, O. L., Watson, A., \& Kirby, D. A. (2012). Toward a model of franchisee entrepreneurship. International Small Business Journal, 30(5), 559-583. https://doi.org/ $10.1177 / 0266242610376078$

De Silva, M., \& Wright, M. (2019). Entrepreneurial co-creation: Societal impact through open innovation. $R \& D$ Management Journal, 49(3), 318-342. https://doi.org/10. 1111/radm.12362

Dess, G. G., Ireland, R. D., Zahra, S. A., Floyd, S. W., Janney, J. J., \& Lane, P. J. (2003). Emerging issues in corporate entrepreneurship. Journal of Management, 29(3), 351378. https://doi.org/10.1016/S0149-2063(03)00015-1

Djankov, S., La Porta, R., Lopez-De-Silanes, F., \& Shleifer, A. (2002). The regulation of entry. Quarterly Journal of Economics, 117(1), 1-37. https://doi.org/10.1162/00335 5302753399436

Doh, J. P., \& Pearce, J. A. (2004). Corporate entrepreneurship and real options in transitional policy environments: Theory development. Journal of Management Studies, 41(4), 645-664. https://doi.org/10.1111/j.1467-6486. 2004.00448.x

Dokko, G., \& Gaba, V. (2012). Venturing into new territory: Career experiences of corporate venture capital managers and practice variation. Academy of Management Journal, 55(3), 563-583. https://doi.org/10.5465/amj.2009.0909
Dushnitsky, G., \& Lenox, M. J. (2005). When do firms undertake R\&D by investing in new ventures? Strategic Management Journal, 26(10), 947-965. https://doi.org/10. 1002/smj.488

Dushnitsky, G., \& Shapira, Z. (2010). Entrepreneurial finance meets organizational reality: Comparing investment practices and performance of corporate and independent venture capitalists. Strategic Management Journal, 31(9), 990-1017. https://doi.org/10.1002/smj.851

Foss, N. J., Lyngsie, J., \& Zahra, S. A. (2013). The role of external knowledge sources and organizational design in the process of opportunity exploitation. Strategic Management Journal, 34(12), 1453-1471. https://doi.org/10. 1002/smj.2135

Glaser, L., Fourné, S. P., \& Elfring, T. (2015). Achieving strategic renewal: The multi-level influences of top and middle managers' boundary-spanning. Small Business Economics, 45(2), 305-327. https://doi.org/10.1007/ s11187-015-9633-5

Gnyawali, D. R., \& Fogel, D. S. (1994). Environments for entrepreneurship development: key dimensions and research implications. Entrepreneurship: Theory and Practice, 18(4), 43-62. https://doi.org/10.1177/10422 5879401800403

Grande, J., Madsen, E. L., \& Borch, O. J. (2011). The relationship between resources, entrepreneurial orientation and performance in farm-based ventures. Entrepreneurship and Regional Development, 23(3-4), 89-111. https://doi. org/10.1080/08985620903183710

Grossman, A., Okhmatovskiy, I., \& Wright, M. (2016). State control and corporate governance in transition economies: 25 years on from 1989. Corporate GovernanceInternational Review, 24(3), 200-221. https://doi.org/10. 1111/corg.12145

Guerrero, M., Amorós, J. E., \& Urbano, D. (2021). Do employees' generational cohorts influence corporate venturing? A multilevel analysis. Small Business Economics, 57(1), 47-74. https://doi.org/10.1007/ s11187-019-00304-z.

Guth, W. D., \& Ginsberg, A. (1990). Guest editors' introduction: Corporate entrepreneurship. Strategic Management Journal, 11, 5-15.

Hale, J. S., \& Woronkowicz, J. (2020). Artists as public sector intrapreneurs: an experiment. Small Business Economics, 1-14.https://doi.org/10.1007/s11187-020-00417-w

Hayton, J., George, G., \& Zahra, S. (2002). National culture and entrepreneurship: A review of behavioral research. Entrepreneurship Theory and Practice, 26(4), 33-52. https://doi.org/10.1177/104225870202600403

Heavey, C., \& Simsek, Z. (2013). Top Management compositional effects on corporate entrepreneurship: The moderating role of perceived technological uncertainty. Journal of Product Innovation Management, 30(5), 837-855. https://doi.org/10.1111/jpim.12033

Heavey, C., Simsek, Z., Roche, F., \& Kelly, A. (2009). Decision comprehensiveness and corporate entrepreneurship: The moderating role of managerial uncertainty preferences and environmental dynamism. Journal of Management Studies, 46(8), 1289-1314. https://doi.org/10. 1111/j.1467-6486.2009.00858.x 
Hellman, T. (2007). When do employees become entrepreneurs? Management Science, 53(6), 919-933. https://doi. org/10.1287/mnsc. 1060.0648

Hills, G., \& LaForge, R. (1992). Research at the marketing interface to advance entrepreneurship theory. Entrepreneurship Theory and Practice, 16(3), 33-59. https://doi. org/10.1177/104225879201600303

Hitt, M. A., Ireland, R. D., Camp, S. M., \& Sexton, D. L. (2001). Strategic entrepreneurship: Entrepreneurial strategies for wealth creation. Strategic Management Journal, 22(6-7), 479-491. https://doi.org/10.1002/smj.196

Hornsby, J. S., Kuratko, D. F., \& Zahra, S. A. (2002). Middle managers' perception of the internal environment for corporate entrepreneurship: Assessing a measurement scale. Journal of Business Venturing, 17(3), 253-273. https:// doi.org/10.1016/S0883-9026(00)00059-8

Hornsby, J. S., Kuratko, D. F., Shepherd, D. A., \& Bott, J. P. (2009). Managers' corporate entrepreneurial actions: Examining perception and position. Journal of Business Venturing, 24(3), 236-247. https://doi.org/10.1016/j. jbusvent.2008.03.002

Hornsby, J. S., Peña-Legazkue, I., \& Guerrero, M. (2013a). Guest editorial: The role of corporate entrepreneurship in the current organizational and economic landscape. International Entrepreneurship and Management Journal, 9, 1-11. https://doi.org/10.1007/s11365-013-0255-6

Hornsby, J. S., Bloodgood, J. M., Hayton, J., \& Kuratko, D. F. (2013b). Network legitimacy diffusion: A model for corporate entrepreneurship. International Entrepreneurship and Management Journal, 9(3), 307-322. https://doi.org/ 10.1007/s11365-013-0256-5

Hoy, F. (2006). The complicating factor of life cycles in corporate venturing. Entrepreneurship Theory and Practice, 30(6), 831-836. https://doi.org/10.1111/j.1540-6520.2006.00154.X

Hughes, M., \& Mustafa, M. (2017). Antecedents of corporate entrepreneurship in SMEs: Evidence from an emerging economy. Journal of Small Business Management, 55(S1), 115-140. https://doi.org/10.1111/jsbm.12269

Ireland, R. D., Hitt, M. A., \& Sirmon, D. G. (2003). A model of strategic entrepreneurship: The construct and its dimensions. Journal of Management, 29(6), 963-989. https:// doi.org/10.1016/S0149-2063(03)00086-2

Ireland, R. D., Covin, J. G., \& Kuratko, D. F. (2009). Conceptualizing corporate entrepreneurship strategy. Entrepreneurship Theory and Practice, 33(1), 19-46. https://doi. org/10.1111/j.1540-6520.2008.00279.x

Jones, M. V., Coviello, N., \& Tang, Y. K. (2011). International entrepreneurship research (1989-2009): a domain ontology and thematic analysis. Journal of Business Venturing, 26(6), 632-659. https://doi.org/10.1016/j.jbusvent. 2011.04.001

Judge, W. Q., Liu-Thompkins, Y., Brown, J. L., \& Pongpatipat, C. (2015). The impact of home country institutions on corporate technological entrepreneurship via $R \& D$ investments and virtual world presence. Entrepreneurship Theory and Practice, 39(2), 237-266. https://doi. org/10.1111/etap.12036

Kacperczyk, A. J. (2012). Opportunity structures in established firms entrepreneurship versus intrapreneurship in mutual funds. Administrative Science Quarterly, 57(3), 484-521. https://doi.org/10.1177/0001839212462675
Kang, J. H., Matusik, J. G., Kim, T. Y., \& Phillips, J. M. (2016). Interactive effects of multiple organizational climates on employee innovative behavior in entrepreneurial firms: A cross-level investigation. Journal of Business Venturing, 31(6), 628-642. https://doi.org/10.1016/j.jbusvent.2016. 08.002

Kellermanns, F. W., \& Eddleston, K. A. (2006). Corporate entrepreneurship in family firms: A family perspective. Entrepreneurship Theory and Practice, 30(6), 809-830. https://doi.org/10.1111/j.1540-6520.2006.00153.x

Kelley, D. J., Peters, L., \& O'Connor, G. C. (2009). Intraorganizational networking for innovation-based corporate entrepreneurship. Journal of Business Venturing, 24(3), 221-235. https://doi.org/10.1016/j.jbusvent.2008.05.010

Keupp, M. M., \& Gassmann, O. (2009). The past and the future of international entrepreneurship: A review and suggestions for developing the field. Journal of Management, 35(3), 600-633. https://doi.org/10.1177/0149206308 330558

Kistruck, G. M., \& Beamish, P. W. (2010). The interplay of form, structure, and embeddedness in social intrapreneurship. Entrepreneurship Theory and Practice, 34(4), 735-761. https://doi.org/10.1111/j.1540-6520.2010. 00371.x

Kolev, K. D., Wangrow, D. B., Barker, V. L., III., \& Schepker, D. J. (2019). Board committees in corporate governance: A cross-disciplinary review and agenda for the future. Journal of Management Studies, 56(6), 1138-1193. https://doi.org/10.1111/joms.12444

Kotlar, J., DeMassis, A., Wright, M., \& Frattini, F. (2018). Organizational goals: Antecedents, formation processes, and implications for firm behavior and performance. International Journal of Management Reviews, 20, S3S18. https://doi.org/10.1111/ijmr.12170

Kreiser, P. M., Marino, L. D., \& Weaver, K. M. (2002). Assessing the psychometric properties of the entrepreneurial orientation scale: A multi-country analysis. Entrepreneurship Theory and Practice, 26(4), 71-94. https://doi. org/10.1177/104225870202600405

Kreiser, P. M., Kuratko, D. F., Covin, J. G., Ireland, R. D., \& Hornsby, J. S. (2021). Corporate entrepreneurship strategy: extending our knowledge boundaries through configuration theory. Small Business Economics, 56, 739-758. https://doi.org/10.1007/s11187-019-00198-x

Kuratko, D. F., \& Audretsch, D. B. (2013). Clarifying the domains of corporate entrepreneurship. International Entrepreneurship and Management Journal, 9(3), 1-13. https://doi.org/10.1007/s11365-013-0257-4

Kuratko, D. F., Morris, M. H., \& Covin, J. G. (2011). Corporate Innovation \& Entrepreneurship (International Edition) (3rd ed.). South-Western/Cengage Learning.

Kuratko, D. F., Hornsby, J. S., \& Hayton, J. (2015). Corporate entrepreneurship: The innovative challenge for a new global economic reality. Small Business Economics, 45(2), 245-253. https://doi.org/10.1007/ s11187-015-9630-8

Kuratko, D. F., Hornsby, J. S., \& McKelvie, A. (2021). Entrepreneurial mindset in corporate entrepreneurship: Forms, impediments, and actions for research. Journal of Small Business Management, 1-23.https://doi.org/ 10.1080/00472778.2021.1907585 
Lampe, J., Kraft, P. S., \& Bausch, A. (2020). Mapping the field of research on entrepreneurial organizations (1937-2016): A bibliometric analysis and research agenda. Entrepreneurship Theory and Practice, 44(4), 784-816. https://doi.org/10.1177/1042258719851217

López-Duarte, C., Vidal-Suárez, M. M., \& González-Díaz, B. (2016). International business and national culture: A literature review and research agenda. International Journal of Management Reviews, 18(4), 397-416. https://doi.org/10.1111/ijmr.12070

Lumpkin, G. T., \& Dess, G. G. (1996). Clarifying the entrepreneurial orientation construct and linking it to performance. Academy of Management Review, 21(1), 135-172. https://doi.org/10.2307/258632

Lyngsie, J., \& Foss, N. J. (2017). The more, the merrier? Women in top-management teams and entrepreneurship in established firms. Strategic Management Journal, 38(3), 487-505. https://doi.org/10.1002/smj.2510

Maes, J., \& Sels, L. (2014). SMEs' radical product innovation: The role of internally and externally oriented knowledge capabilities. Journal of Small Business Management, 52(1), 141-163. https://doi.org/10.1111/ jsbm. 12037

Martiarena, A. (2013). What's so entrepreneurial about intrapreneurs? Small Business Economics, 40(1), 27-39. https://doi.org/10.1007/s11187-011-9348-1

Marvel, M. R., Griffin, A., Hebda, J., \& Vojak, B. (2007). Examining the technical corporate entrepreneurs' motivation: Voices from the field. Entrepreneurship Theory and Practice, 31(5), 753-768. https://doi.org/10.1111/j. 1540-6520.2007.00198.x

Marvel, M. R., Davis, J. L., \& Sproul, C. R. (2016). Human capital and entrepreneurship research: A critical review and future directions. Entrepreneurship Theory and Practice, 40(3), 599-626. https://doi.org/10.1111/etap. 12136

Maula, M. V., Autio, E., \& Murray, G. C. (2009). Corporate venture capital and the balance of risks and rewards for portfolio companies. Journal of Business Venturing, 24(3), 274-286. https://doi.org/10.1016/j.jbusvent.2008. 10.012

McCain, K. W. (1983). The author cocitation structure of macroeconomics. Scientometrics, 5(5), 277-289. https://doi. org/10.1007/BF02147224

McGrath, R. G., Venkataraman, S., \& MacMillan, I. C. (1994). The advantage chain: Antecedents to rents from internal corporate ventures. Journal of Business Venturing, 9(5), 351-369. https://doi.org/10.1016/0883-9026(94) 90012-4

McMillan, I. C. (1986). Progress in research on corporate venturing. In D. L. Sexton \& R. W. Smilor (Eds.), The Art and Science of Entrepreneurship. Cambridge: Ballinger Publishing Company.

Miller, D. (1983). The correlates of entrepreneurship in three types of firms. Management Science, 27(7), 770-791. https://doi.org/10.1287/mnsc.29.7.770

Miller, A., Wilson, B., \& Adams, M. (1988). Financial performance patterns of new corporate ventures: An alternative to traditional measures. Journal of Business Venturing, 3(4), 287-300. https://doi.org/10.1016/0883-9026(88) 90010-9
Miller, A., Spann, M. S., \& Lerner, L. (1991). Competitive advantages in new corporate ventures: The impact of resource sharing and reporting level. Journal of Business Venturing, 6(5), 335-350. https://doi.org/10.1016/08839026(91)90023-7

Minola, T., Brumana, M., Campopiano, G., Garrett, R. P., \& Cassia, L. (2016). Corporate venturing in family business: A developmental approach of the enterprising family. Strategic Entrepreneurship Journal, 10(4), 395-412. https://doi.org/10.1002/sej.1236

Minola, T., Kammerlander, N., Kellermanns, F. W., \& Hoy, F. (2021). Corporate entrepreneurship and family business: Learning across domains. Journal of Management Studies, 58(1), 1-26. https://doi.org/10.1111/joms.12672

Monsen, E., Patzelt, H., \& Saxton, T. (2010). Beyond simple utility: Incentive design and trade-offs for corporate employee-entrepreneurs. Entrepreneurship Theory and Practice, 34(1), 105-130. https://doi.org/10.1111/j.15406520.2009.00314.x

Morris, M. H., Avila, R. A., \& Allen, J. W. (1993). Individualism and the modern corporation: Implications for innovation and entrepreneurship. Journal of Management, 19(3), 595-612. https://doi.org/10.1177/0149206393 01900305

Morris, M. H., Davis, D. L., \& Allen, J. W. (1994). Fostering corporate entrepreneurship: Cross-cultural comparisons of the importance of individualism versus collectivism. Journal of International Business Studies, 25(1), 65-89. https://doi.org/10.1057/palgrave.jibs. 8490849

Mourao, P. R., \& Martinho, V. D. (2020). Forest entrepreneurship: A bibliometric analysis and a discussion about the co-authorship networks of an emerging scientific field. Journal of Cleaner Production, 256, 120413. https://doi. org/10.1016/j.jclepro.2020.120413

Narayanan, V. K., Yang, Y., \& Zahra, S. A. (2009). Corporate venturing and value creation: A review and proposed framework. Research Policy, 38(1), 58-76. https://doi. org/10.1016/j.respol.2008.08.015

Nason, R. S., McKelvie, A., \& Lumpkin, G. T. (2015). The role of organizational size in the heterogeneous nature of corporate entrepreneurship. Small Business Economics, 42(2), 1-26. https://doi.org/10.1007/s11187-015-9632-6

O'connor, G. C., \& Rice, M. P. (2001). Opportunity recognition and breakthrough innovation in large established firms. California Management Review, 43(2), 95-116. https://doi.org/10.2307/41166077

Park, H. D., \& Steensma, H. K. (2012). When does corporate venture capital add value for new ventures? Strategic Management Journal, 33(1), 1-22. https://doi.org/10. $1002 /$ smj. 937

Parker, S. C. (2011). Intrapreneurship or entrepreneurship? Journal of Business Venturing, 26(1), 19-34. https://doi. org/10.1016/j.jbusvent.2009.07.003

Pettit, K. L., \& Crossan, M. M. (2020). Strategic renewal: Beyond the functional resource role of occupational members. Strategic Management Journal, 41(6), 11121138. https://doi.org/10.1002/smj.3115

Phan, P. H., Wright, M., Ucbasaran, D., \& Tan, W. L. (2009). Corporate entrepreneurship: Current research and future directions. Journal of Business Venturing, 24(3), 197205. https://doi.org/10.1016/j.jbusvent.2009.01.007 
Pinchot, G. (1985). Intrapreneurship. Harper \& Row.

Plambeck, N. (2012). The development of new products: The role of firm context and managerial cognition. Journal of Business Venturing, 27(6), 607-621. https://doi.org/10. 1016/j.jbusvent.2011.08.002

Post, C., Sarala, R., Gatrell, C., \& Prescott, J. E. (2020). Advancing theory with review articles. Journal of Management Studies, 57(2), 351-376. https://doi.org/10. 1111/joms. 12549

Radaelli, G., \& Sitton-Kent, L. (2016). Middle managers and the translation of new ideas in organizations: A review of micro-practices and contingencies. International Journal of Management Reviews, 18(3), 311-332. https://doi.org/ 10.1111/ijmr.12094

Ramos-Rodriguez, A. R., \& Ruiz-Navarro, J. (2004). Changes in the intellectual structure of strategic management research: A bibliometric study of the Strategic Management Journal, 1980-2000. Strategic Management Journal, 25(10), 981-1004. https://doi.org/10.1002/smj.397

Rind, K. W. (1981). The role of venture capital in corporate development. Strategic Management Journal, 2(2), 169180. https://doi.org/10.1002/smj.4250020206

Romero-Martínez, A. M., Fernández-Rodríguez, Z., \& Vázquez-Inchausti, E. (2010). Exploring corporate entrepreneurship in privatized firms. Journal of World Business, 45(1), 2-8. https://doi.org/10.1016/j.jwb.2009.04. 008

Sahaym, A., Steensma, H. K., \& Barden, J. Q. (2010). The influence of R\&D investment on the use of corporate venture capital: An industry-level analysis. Journal of Business Venturing, 25(4), 376-388. https://doi.org/10. 1016/j.jbusvent.2008.12.001

Salvato, C., Sciascia, S., \& Alberti, F. (2009). The microfoundations of corporate entrepreneurship as an organizational capability. The International Journal of Entrepreneurship and Innovation, 10(4), 279-289. https://doi.org/ 10.5367/000000009790012291

Sathe, V. (1985). Managing an entrepreneurial dilemma: nurturing entrepreneurship and control in large corporations. Frontiers of Entrepreneurship Research, Babson College, Wesley Mas, pp. 636-656.

Schildt, H. A., Maula, M. V., \& Keil, T. (2005). Explorative and exploitative learning from external corporate ventures. Entrepreneurship Theory and Practice, 29(4), 493-515. https://doi.org/10.1111/j.1540-6520.2005. 00095.x

Schildt, H. A., Zahra, S. A., \& Sillanpää, A. (2006). Scholarly communities in entrepreneurship research: A co-citation analysis. Entrepreneurship Theory and Practice, 30(3), 399-415. https://doi.org/10.1111/j.1540-6520.2006. 00126.x

Schollhammer, H. (1982). Internal corporate entrepreneurship. In C. Kent, D. Sexton, \& K. Vesper (Eds.), Encyclopedia of entrepreneurship. Prentice-Hall.

Shafique, M. (2013). Thinking inside the box? Intellectual structure of the knowledge base of innovation research (1988-2008). Strategic Management Journal, 34(1), 62-93. https://doi.org/10.1002/smj.2002

Shane, S. (2000). Prior knowledge and the discovery of entrepreneurial opportunities. Organization Science, 11(4), 448-469. https://doi.org/10.1287/orsc.11.4.448.14602
Sharma, P., \& Chrisman, J. J. (1999). Toward a reconciliation of the definitional issues in the field of corporate entrepreneurship. Entrepreneurship Theory and Practice, 23(3), 11-28. https://doi.org/10.1287/orsc.11.4.448.14602

Shepherd, D. A., Covin, J. G., \& Kuratko, D. F. (2009). Project failure from corporate entrepreneurship: Managing the grief process. Journal of Business Venturing, 24(6), 588-600. https://doi.org/10.1016/j.jbusvent.2008.01.009

Shepherd, D. A., Williams, T. A., \& Patzelt, H. (2015). Thinking about entrepreneurial decision making: Review and research agenda. Journal of Management, 41(1), 11-46. https://doi.org/10.1177/0149206314541153

Simba, A., \& Thai, M. T. T. (2019). Advancing entrepreneurial leadership as a practice in MSME management and development. Journal of Small Business Management, 57(sup2), 397-416. https://doi.org/10.1111/jsbm.12481

Simsek, Z., Veiga, J. F., \& Lubatkin, M. H. (2007). The impact of managerial environmental perceptions on corporate entrepreneurship: Towards understanding discretionary slack's pivotal role. Journal of Management Studies, 44(8), 13981424. https://doi.org/10.1111/j.1467-6486.2007.00714.x

Small, H. (1973). Co-citation in the scientific literature: A new measure of the relationship between two documents. Journal of the Association for Information Science and Technology, 24(4), 265-269. https://doi.org/10.1002/asi. 4630240406

Stam, E. (2013). Knowledge and entrepreneurial employees: A country-level analysis. Small Business Economics, 41(4), 887-898. https://doi.org/10.1007/s11187-013-9511-y

Tsai, W. M. H., MacMillan, I. C., \& Low, M. B. (1991). Effects of strategy and environment on corporate venture success in industrial markets. Journal of Business Venturing, 6(1), 9-28. https://doi.org/10.1016/0883-9026(91)90003-V

Turner, T., \& Pennington, W. W., III. (2015). Organizational networks and the process of corporate entrepreneurship: How the motivation, opportunity, and ability to act affect firm knowledge, learning, and innovation. Small Business Economics, 45(2), 447-463. https://doi. org/10.1007/s11187-015-9638-0

Turro, A., Urbano, D., \& Peris-Ortiz, M. (2014). Culture and innovation: The moderating effect of cultural values on corporate entrepreneurship. Technological Forecasting and Social Change, 88, 360-369.

Turro, A., Alvarez, C., \& Urbano, D. (2016). Intrapreneurship in the Spanish context: A regional analysis. Entrepreneurship \& Regional Development, 28(5-6), 380402. https://doi.org/10.1080/08985626.2016.1162850

Urbano, D., Aparicio, S., \& Audretsch, D. (2019). Twentyfive years of research on institutions, entrepreneurship, and economic growth: What has been learned? Small Business Economics, 53(1), 21-49. https://doi.org/10. 1007/s11187-018-0038-0

Van Eck, N. J., \& Waltman, L. (2010). Software survey: VOSviewer, a computer program for bibliometric mapping. Scientometrics, 84(2), 523-538. https://doi.org/ 10.1007/s11192-009-0146-3

Verbeke, A., Chrisman, J. J., \& Yuan, W. (2007). A note on strategic renewal and corporate venturing in the subsidiaries of multinational enterprises. Entrepreneurship Theory and Practice, 31(4), 585-600. https://doi.org/10. 1111/j.1540-6520.2007.00189.x 
Volery, T., \& Mazzarol, T. (2015). The evolution of the small business and entrepreneurship field: A bibliometric investigation of articles published in the International Small Business Journal. International Small Business Journal, 33(4), 374-396. https://doi.org/10.1177/02662 42613516139

Wadhwa, A., \& Kotha, S. (2006). Knowledge creation through external venturing: Evidence from the telecommunications equipment manufacturing industry. Academy of Management Journal, 49(4), 819-835. https://doi.org/10.2307/20159800

Wadhwa, A., Phelps, C., \& Kotha, S. (2016). Corporate venture capital portfolios and firm innovation. Journal of Business Venturing, 31(1), 95-112. https://doi.org/10. 1016/j.jbusvent.2015.04.006

Wallin, M. W. (2012). The bibliometric structure of spinoff literature. Innovation, 14(2), 162-177. https://doi. org/10.5172/impp.2012.14.2.162

Walter, A., Auer, M., \& Ritter, T. (2006). The impact of network capabilities and entrepreneurial orientation on university spin-off performance. Journal of Business Venturing, 21(4), 541-567. https://doi.org/10.1016/j. jbusvent.2005.02.005

Wang, Y. K. M., Chung, C. C., \& Lim, D. S. (2015). The drivers of international corporate entrepreneurship: CEO incentive and CEO monitoring mechanisms. Journal of World Business, 50(4), 742-753. https://doi. org/10.1016/j.jwb.2015.02.002

Westfall, S. L. (1969). Stimulating Corporate Entrepreneurship in U.S. industry. Strategic Management Journal, 12(2), 235-246. https://doi.org/10.2307/254819

Wooldridge, B., Schmid, T., \& Floyd, S. W. (2008). The middle management perspective on strategy process: Contributions, synthesis, and future research. Journal of Management, 34(6), 1190-1221. https://doi.org/10. $1177 / 0149206308324326$

Wright, M., Thompson, S., \& Robbie, K. (1992). Venture capital and management-led leveraged buy-outs. Journal of Business Venturing, 7(1), 47-71. https://doi.org/10.1016/ 0883-9026(92)90034-O

Zahra, S. A. (1991). Predictors and financial outcomes of corporate entrepreneurship: An exploratory study. Journal of Business Venturing, 6(4), 259-286. https://doi.org/10. 1016/0883-9026(91)90019-A

Zahra, S. A. (1993). Environment, corporate entrepreneurship and financial performance: A taxonomic approach. Journal of Business Venturing, 8(4), 319-340. https://doi.org/ 10.1016/0883-9026(93)90003-N
Zahra, S. A. (1995). Corporate entrepreneurship and financial performance: The case of management leveraged buyouts. Journal of Business Venturing, 10(3), 225-247. https://doi.org/10.1016/0883-9026(94)00024-O

Zahra, S. A. (1996a). Governance, ownership, and corporate entrepreneurship: The moderating impact of industry technological opportunities. Academy of Management Journal, 39(6), 1713-1735. https://doi.org/10.2307/ 257076

Zahra, S. A. (1996b). Technology strategy and new venture performance: A study of corporate-sponsored and independent biotechnology ventures. Journal of Business Venturing, 11(4), 289-321. https://doi.org/10.1016/08839026(95)00128-X

Zahra, S. A., \& Covin, J. G. (1995). Contextual influences on the corporate entrepreneurship-performance relationship: A longitudinal analysis. Journal of Business Venturing, 10(1), 43-58. https://doi.org/10.1016/0883-9026(94)00004-E

Zahra, S. A., \& Garvis, D. M. (2000). International corporate entrepreneurship and firm performance: The moderating effect of international environmental hostility. Journal of Business Venturing, 15(5), 469-492. https://doi.org/10. 1016/S0883-9026(99)00036-1

Zahra, S. A., \& Hayton, J. (2008). The effect of international venturing on firm performance: The moderating influence of absorptive capacity. Journal of Business Venturing, 23(2), 195-220. https://doi.org/10.1016/j.jbusvent. 2007.01.001

Zahra, S. A., Nielsen, A. P., \& Bogner, W. C. (1999). Corporate entrepreneurship, knowledge, and competence development. Entrepreneurship Theory and Practice, 23(3), 169-189. https://doi.org/10.1177/104225879902300310

Zahra, S. A., Neubaum, D. O., \& Huse, M. (2000). Entrepreneurship in medium-size companies: Exploring the effects of ownership and governance systems. Journal of Management, 26(5), 947-976. https://doi.org/10.1016/ S0149-2063(00)00064-7

Zahra, S. A., Filatotchev, I., \& Wright, M. (2009). How do threshold firms sustain corporate entrepreneurship? The role of boards and absorptive capacity. Journal of Business Venturing, 24(3), 248-260. https://doi.org/10. 1016/j.jbusvent.2008.09.001

Publisher's note Springer Nature remains neutral with regard to jurisdictional claims in published maps and institutional affiliations. 